\title{
DYNAMIC RELATIONSHIP BETWEEN CAPITAL INFLOWS AND BANK LENDING: THE ROLE OF COMMODITY PRICE AND GLOBAL FINANCIAL MARKET SHOCKS
}

\author{
Doni Satria*, Nachrowi Djalal Nachrowi**, Telisa A. Falianty**, and \\ Iskandar Simorangkir*** \\ * Corresponding author. Fakultas Ekonomi, Padang State University and Universitas Indonesia, \\ Indonesia. Email: donisatria@fe.unp.ac.id \\ ** Universitas Indonesia, Indonesia. \\ *** Ministry of Economic Coordinator Republic of Indonesia, Indonesia.
}

\begin{abstract}
This paper investigates the dynamic relationship between capital inflows and bank lending in Indonesia. We use a Structural Vector AutoRegression (SVAR) model that allows exogenous international commodity prices and global financial market fluctuations to influence capital inflows. We find that commodity price shocks are more important as compared to global financial shocks in explaining the variance of capital inflows in the long run. Furthermore, shocks from capital inflows lead to a change in bank lending allocation across economic sectors.
\end{abstract}

Keywords: Commodity price shocks; Capital inflows; Bank lending; Financial stability. JEL Classifications: F410; F320; G210; O160.

\author{
Article history: \\ Received : October 15, 2019 \\ Revised : March 29, 2020 \\ Accepted : June 10, 2021 \\ Available Online: December 31,2021 \\ https://doi.org/10.21098/bemp.v24i4.1170
}




\section{INTRODUCTION}

The conventional wisdom indicates that global factors were mostly responsible for the surge of capital inflows to the emerging economies in the last three decades. The surge of capital inflows leads to greater volatility and, eventually, to large reversals of the inflows because of changes in expected asset returns, investor herding, and contagion effects. A large capital inflow, induced by the global push factors, could lead to financial vulnerabilities as well as the misallocation of financial resources. Following the 2008 global financial crisis, the surges of capital inflows to Asian economies led to misallocation of financial resources (Balakrishnan et al., 2013). Cerutti et al. (2019) show gross inflows to emerging market economies co-move greatly across countries as a result of global push factors, and that the magnitude of these effects vary substantially across countries.

The macroeconomic challenges, triggered by the surge in capital flows, have given rise to a large literature addressing the appropriate policy responses, in particular, to prevent economic overheating and limit vulnerability to the large reversal of capital flows. ${ }^{1}$ Countercyclical policies, including tight monetary and macroprudential policies, greater flexibility in the exchange rate regime, and capital flow management policies, including occasional capital control and banking supervision and regulation, have been to limit capital flows.

The dynamics of capital flows in the developing countries are highly influenced by global financial cycles, and countries with high capital inflows tend to be more responsive to global financial cycles (Cerutti et al., 2019; Davis and Presno, 2014; Forbes and Warnock, 2012; Rey, 2015; Warjiyo, 2014). Nonetheless, little has been known about the interaction between commodity prices and capital inflows, particularly, in commodity-dependent developing economies. Separate analysis of international macroeconomics and international trade fails to account for the influence of international trade on macroeconomic dynamics (Jin, 2012).

Our objective is to investigate the relative importance of commodity prices and global financial market fluctuations as the global push factors in Indonesia's capital inflows. Indonesia is one of the highly sensitive countries to the global push factors of capital inflows along with Brazil, South Africa, Thailand, and Turkey (Cerutti et al., 2019). Volatile commodity prices and global financial markets associated with the volatile capital flows during the 2010-2012 period complicated the conduct of monetary policy in Indonesia (Warjiyo, 2012).

Our study captures commodity prices and global financial market fluctuations in an SVAR model as global push factors of capital inflows. ${ }^{2}$ The commodity price is a domestic pull factor of capital flows in some studies (Antràs and Caballero, 2009; Cerutti et al., 2019; Dreschel and Tenreyro, 2017; Fernández, 2018; Shousa, 2016) and a global push factor in other studies (Bastourre et al., 2012; Byrne and Fiess, 2016; Davis et al., 2019; Reinhart et al., 2016). Nonetheless, the role of

\footnotetext{
See (Koepke, 2019) for a recent survey of the literature on the drivers of capital flows.

2 Based on Antràs and Caballero (2009) and the portfolio choice theoretical framework, this study develops the hypothesis that commodity prices not only increase the return on capital (the pull factor) but also shift global investors' risk perception (the push factor) on asset prices of more financially constrained commodity-dependent economies. Empirically (Byrne and Fiess, 2016) also support this theoretical ground-commodity price is a global push factor instead of a domestic pull factor.
} 
commodity prices as a global factor of capital inflows is inconclusive, and the relative importance of commodity prices to the global financial cycle has not been explored. As already known within the capital flow drivers literature, the source of the heterogeneous response of emerging countries' capital flows to the global factors is the economic structure of the emerging economies (Cerutti et al., 2019; Davis et al., 2019).

In terms of global financial markets, Rey (2015) found the global financial cycle was closely related to the monetary policy of center countries like the USA, which affects the leverage of global banks, credit growth, and credit flows within the international financial system. Forbes and Warnock (2012) reveal that global risk factors are the main drivers of international capital flows and that domestic variables only have limited correlation with the capital flow volatility. On the contrary, Cerutti et al., (2019) discovered that the global financial cycle plays a smaller role in capital flows than implied by the results of the current literature on capital flows determinants. They reveal that most of the variations in capital flows are neither the result of common shocks nor stem from observables in a center country like the USA. According Byrne and Fiess (2016), the US monetary policy, which operates through short-term interest rates, has a relatively less powerful effect, while real commodity prices appear to have a more powerful effect on capital flows, as the global push factor.

We set both the commodity price and global financial market fluctuation as strictly exogenous variables to examine their relative importance to capital flows. Identifying the relative importance of both global factors is an important empirical subject of analysis for Indonesia and other commodity-dependent emerging economies. Given their economic structure, the capital inflow effect on the misallocation of the financial resources between sectors should be considered by the policymakers in commodity-dependent emerging economies. The countercyclical policies implemented during high capital inflow episodes should consider bank lending allocation and sectoral growth stability.

We also investigate the effect of this capital inflow (conditional on the exogenous factors) on the bank lending allocation across sectors in a commodity-dependent economy. The effect of capital inflows on financial resource allocation has been rarely explored in the literature. The previous literature focused on the financial sector and macroeconomic stability effects of capital inflows to emerging economies. In their paper, Balakrishnan et al. (2013) found evidence of disequilibrium process and misallocation of financial resources following the fast-growing capital inflows to emerging Asian economies. They concluded, disequilibrium and misallocation of financial resources, probably trigger a financial crisis. Lartey (2008) investigates the effects of capital inflows on resource reallocation and real exchange rate movements in a small open economy. He observed that there exists a trade-off between resource reallocation and the degree of real exchange rate appreciation. Thus, for a commodity-dependent economy, high capital inflow episodes could change the resource allocation between sectors (Dutch disease) because of exchange rate stabilization policies.

Within the literature on the effect of capital inflows on the domestic economy, our work relates to Samarina and Bezemer (2016), who document that foreign capital inflows are associated with a lower share of bank lending to the business 
sector and a higher share of bank lending to the non-business sector. Furthermore, Benigno et al. (2015) found that periods of large capital inflows are accompanied by credit booms and resource drift from the manufacturing sector to the non-tradable sector in emerging European countries.

Based on the above theoretical prediction, we derive our hypothesis that an increase in the international commodity prices, as a global push factor, should induce capital inflows to a less financially developed commodity-dependent economy. Moreover, the commodity price induced capital inflows alter the allocation of bank lending across sectors due to the differences in the financial friction across economic sectors. Capital inflows induced by rising commodity prices expand bank lending in the domestic economy, but not uniformly across all sectors.

To examine our theoretical prediction, we employ an SVAR model, which consists of seven structural equations with two strictly exogenous variables, the commodity price and the global financial condition, and five domestic endogenous variables. In the first step of estimating the reduced form VAR, we place restrictions to ensure there is no feedback from the endogenous variables to the strictly exogenous global push factors. In the second step of SVAR structural shock estimation, we put restrictions on the contemporaneous effect of the exogenous variables to the relevant endogenous variables implied by the theory.

We use Indonesian quarterly data and estimate this empirical model from the first quarter of 1993 up to the third quarter of 2018. The Indonesian economy has a high share of primary commodities in its total export (UNCTAD, 2017) and banks dominate the country's financial sector (IMF, 2017; Warjiyo, 2012). Indonesia is a commodity-dependent economy, as 62 percent of the country's total export revenue stems from primary commodity export (UNCTAD, 2017). According to IMF (2018), the Indonesian financial sector grew fast from 2005 to 2015, but its development lagged behind the peer countries in developing Asia. As a small open developing economy, Indonesia is financially constrained, lacks institutional investors in its capital market, and its financial system is dominated by the banking sector (IMF, 2017). The effect of capital inflow shock (conditional on an exogenous commodity price shock) on bank lending allocation becomes an important subject of study for the Indonesian economy.

The contribution and main findings of this research are twofold. First, we found that commodity price shocks are more important in explaining the variance of capital inflows over a longer time horizon as compared to global financial market shocks in Indonesia. Davis et al. (2019) found that commodity prices are a more important driver of the gross capital flows in emerging countries, for countries like Indonesian and Thailand. They show that almost 60 percent of the variance of gross capital flows are explained by variations in commodity prices. Moreover, Cerutti et al.(2019) found a significant and robust association between commodity prices and emerging market capital flows. The global financial market shocks immediately affect Indonesian capital inflows. In contrast to the global financial market shocks, the commodity price shocks have a delayed but strong and persistent effect on capital inflows. Thus commodity prices are more important as a global factor in shaping the domestic macroeconomic stability compared to global financial market fluctuations in a commodity-dependent economy. The 
global financial cycle only has a short-run effect on capital flows as explained by Byrne and Fiess (2016) and Cerutti et al. (2019). This short-run effect of the global financial market fluctuations on capital flows is probably not transmitted to the domestic financial cycle expansion as found in the literature.

Second, structural shocks from capital inflows (conditional on both commodity prices and global financial market fluctuations) induce changes in bank lending allocation between economic sectors. We observe the bank lending reallocation between business and non-business sectors, and within the business sector. Our study found evidence of the possibility of a credit boom in the Indonesian economy following a structural capital inflow shock induced by the global push factor. According to Terrones and Mendoza (2008), credit booms are a reflection of country-specific oddly large credit expansions as compared to typical business cycle credit expansions. The bank lending to output ratio in the business sector contracted, but the ratio expanded in the primary commodity sector following a structural capital inflow shock. We add to the literature on the effect of capital inflows on bank lending reallocation by showing that capital inflows do not only shift out resources from the manufacturing sector (Benigno et al., 2015) and expand bank lending to the non-tradable sector (Samarina and Bezemer, 2016), but they also cause a persistent expansion of bank lending to commodity producers. The capital inflows expand bank lending to the primary commodity producers faster than output expansion. Our results also confirm Lartey's (2008) finding on resource reallocation or Dutch disease - in this study, we specifically document a financial Dutch disease.

To ensure the robustness of the results, we decompose the capital inflows into debt-based and equity-based capital inflows ${ }^{3}$. Also, we estimate the reduced form VARX model to assess the statistical significance of the commodity price and the global financial market fluctuation on capital inflows measures. We observed the effect of commodity price is robust across sectors and capital inflow measures. Furthermore, the response of bank lending allocation across sectors to capital inflow shocks (conditional on the exogenous global factors) is very similar to the SVAR model result.

The policy relevance of this research is as follows. As a global push factor, the commodity price plays an important role in the dynamics of capital inflows. Consequently, policymakers should take into account the observed commodity price behavior in assessing the vulnerability of their sources of external financing. Additionally, the policy-mix between macroprudential policy and capital flow management should be considered as the solution to the macroeconomic stabilization policy during the surge of capital inflows (Korinek and Sandri, 2016), with additional emphasis on the heterogeneous response of economic sectors to capital inflows.

The rest of the paper is organized as follows. The next section elaborates on the theoretical frameworks to develop the hypothesis. Section III presents an empirical model and explains the restriction applied to the SVAR model. In Section IV, we

3 Davis (2015) using a VAR model with external instruments found the short-run macroeconomic effects of exogenous capital inflows are almost entirely due to changes in debt, not equity-based, capital inflows. 
analyze the results and relative importance between the commodity price shock and the global financial market shock as a global factor of capital inflows. In Section $\mathrm{V}$, we examine the robustness of our findings. Section VI provides conclusions, policy relevance, and future research and closes the presentation of this paper.

\section{HYPOTHESIS DEVELOPMENT}

Reinhart et al. (2016) found a close relationship between the capital flow cycle and commodity price cycle. The interaction of capital inflow with the commodity price boom (double bust) is the most potent source of the financial crisis in many countries during the last two hundred years. According to Reinhart et al. (2016), world economic conditions after the Asian Financial Crisis of 1997/98 were characterized by massive capital inflows to developing countries and commodity price boom. This finding reveals global financial market fluctuation as not only the source of the financial sector instability, but also that the commodity price boom and bust have played an important role in shaping the financial sector stability.

Developing countries have high economic and institutional risks, from the perspective of international investors (Alfaro et al., 2008). The institutional structure of developing economies makes the risk profile of investment in these countries is higher relative to developed economies. Periods of high capital inflows to developing countries imply a lower investment risk; this risk is relatively low compared to the expected return of the global investor. Thus, global investors tend to choose relatively safer instrument to invest in developing countries (Arteta $e t$ al., 2003).

From theoretical perspectives, in a more financially constrained small open economy, an increase in domestic trade openness, will induce capital inflow (Antràs and Caballero, 2009). The export price is exogenous for the small open economy and implies not only the global financial market fluctuation but also the international commodity price play an important role in explaining the capital inflow to a commodity-dependent small open economy. Furthermore, the portfolio choice theory predicts that the share of global financial market capital invested in a country increases during periods of high expected returns on capital (Magud et al. 2011). Commodity price boom increases expected returns on capital, hence the share of global capital investment into commodity exporting countries.

\section{A. Commodity Price and Capital Inflow to a Financially Constrained Economy}

According to Antràs and Caballero, (2009), with different levels of financial development and, thus, different financial constraints between developing and advanced economies, trade liberalization induced capital flow from advanced countries to developing countries. We assume, in a small open economy, trade openness and financial development are the structural variables and are less likely to change within a quarter. However, the commodity export prices are more flexible and change frequently; therefore, they should have an important role as a driver of capital inflows. 
Antras and Caballero's (2009) model assumes an economy with two factors, capital $(K)$ and labor $(L)$, and two goods (good 1 and good 2). In a competitive labor market, workers are flexible to move between economic sectors. The notations for the rental rate of capital, wages, and the capital to labor ratio are, respectively, $\delta$, $w$, and $K / L$, while $\mu K$ and $(1-\mu) K$ denote, respectively, the share of capital in the economy assumed to be owned by entrepreneurs and by rentiers. It is assumed sector 1 has financial friction, but sector 2 does not. With this assumption, only $\theta-1$ capital is allocated to sector 1 by the investor from the total capital used in sector 1 , and the investment constraint is:

$$
I^{i} \leq \theta K^{i}=\theta K, \quad \text { for } \theta>1
$$

where $\theta$ is the financial constraint parameter in sector 1 ; lower $\theta$ means higher financial constraint, and higher $\theta$ means lower financial constraint in sector 1 . Because the assumption of financial friction in sector 1, the allocation of capital to sector 1 is $K_{1}=\mu \theta K<\eta K$, where $\eta K$ is the capital allocated to sector 1 in a frictionless economy. An entrepreneur invests an amount of $\theta K$ and $(\theta-1) K$ is borrowed.

Based on the equilibrium condition in the goods market and consumer preference optimization we get $^{4}$ :

$$
(1-\eta) Z(\mu \theta K)^{\alpha}\left(L_{1}\right)^{1-\alpha}=p \eta Z[(1-\mu \theta) K]^{\alpha}\left(L-L_{1}\right)^{1-\alpha}
$$

where $p$, the relative price is,

$$
p=\frac{p_{2}}{p_{1}}=\left[\frac{\mu \theta(1-\eta)}{\eta(1-\mu \theta)}\right]^{\alpha}<1
$$

Financial frictions and the relative price do not distort the allocation of labor across sectors but shift capital to the unconstrained sector 2 . The real rental rate of capital in sector $2(\delta / p)$ is equal to the Marginal Product of Capital $(M P K)$ in sector 2 , and hence we get the rental rate of capital,

$$
\delta=\left(\frac{p_{2}}{p_{1}}\right)^{\frac{1}{\alpha}} \alpha Z\left(\frac{\mu \theta}{\eta} \frac{K}{L}\right)^{\alpha-1}
$$

Higher $p_{1}$ (the financially constrained sector price) decreases the rental rate of capital in the unconstrained sector 2 . The price increase in sector 1 would shift capital from sector 2 to the more constrained sector 1 .

4 Refer to Antras and Caballero's (2009) baseline model to derive Equation (2) and (3). 
In the open economy set up, the relative price become exogenous for a small open economy. The relevant open economy assumptions for commodity exporting country required to explain the effect of financially constrained sector price changes on the return on capital are:

a) There are two countries, domestic and foreign, in a world with no trade and capital flow friction between countries. The domestic economy is the small open economy and the commodity price is exogenous to this country.

b) There is no difference in production technology and consumer preference in both countries, so the difference is only in financial friction between the two countries. It is assumed foreign countries have higher $\theta$ or lower financial friction than domestic countries (Alfaro et al., 2007; Alfaro et al., 2008). The financial friction is the structural variable and is less likely to change in the short run, but the relative price of output changes frequently.

c) Sector 1 is the primary commodity producer (more financially constrained sector) in the domestic economy, and base on the international trade literature, the domestic economy will specialize and export the primary commodity.

According to Antràs and Caballero (2009), in the open economy, the relative price is exogenous and the equilibrium condition in (2) still holds, but the allocation of labor is not necessarily consistent with goods market-clearing. The equilibrium rental rate of capital in the financially unconstrained sector 2 is:

$$
\delta=\alpha Z \frac{p_{2}}{p_{1}}\left\{\left[(1-\mu \theta)+\mu \theta p^{-1 / \alpha}\right] \frac{K}{L}\right\}^{\alpha-1}
$$

Equation (5) is the open economy rental rate of capital in frictionless sector 2. The rental rate of capital in sector 1 will be equal to that of sector 2 in the frictionless foreign economy and thus higher than that of sector 2 in the domestic economy. With the financially constrained assumption in sector 1 in the domestic small open economy, and lower financial friction parameter value in sector 2 than in the foreign economy, the foreign global investor should obtain a premium over the equilibrium rental rate of capital $(\delta)$ in the foreign country. The rental rate of capital in the domestic small open economy is:

$$
R=\delta+\lambda \theta
$$

where $\lambda$ is the Lagrange multiplier from the investment constraint (1):

$$
\lambda=\left[1-\frac{\mu \theta(1-\eta)}{\eta(1-\mu \theta)}\right] \alpha Z\left(\frac{\mu \theta K}{\eta L}\right)^{\alpha-1}
$$

Hence,

$$
\lambda=\left[1-\frac{p_{2}}{p_{1}}\right]^{\frac{1}{\alpha}} \alpha Z\left(\frac{\mu \theta K}{\eta L}\right)^{\alpha-1}
$$


The financial friction parameter $(\theta)$ is the structural parameter, which is less likely to change in the short run, but the exogenous price $\left(p_{1}\right)$ changes frequently. The exogenous commodity price changes will change the premium over the equilibrium rental rate of capital in a commodity-dependent small open economy. This result provides more incentives for global investors to invest in a commodity exporting economy. Within this framework, commodity price is the domestic pull factor of capital inflow.

From the global investor perspective, the expected return on capital in commodity exporting economy (at the given financial constraint or financial development) increases when exogenous commodity price increase. The return on capital in the commodity sector 1 in the domestic economy also increases relative to the non-commodity sector. The capital inflow from foreign to domestic economy induced by the increasing commodity price also shifts the resource allocation to the commodity sector in the domestic economy. Next, we elaborate on the global investor behavior (global factor) to analyze the supply of capital flow to the commodity-dependent economy.

B. Global Investor Behavior and the Aggregate Supply of Capital Flow to a Commoditydependent Economy

Assume a representative global investor endowed by $F$ financial capital and, for simplicity, this financial capital only consists of $S$ units invested in the commodity exporting economy and $L$ invested in foreign countries' (global) financial market, $(F=S+L) . S$ represents a share of $x$ of total financial capital, such that:

$$
S=x F
$$

The objective function of a global investor is to choose the optimal allocation of total financial capital share $(x)$ in their portfolio allocation. This variable is endogenous and the result from the optimization of global investors.

Based on the standard portfolio choice theory in financial economics (see Bodie et al., 2014; Magud et al., 2011), a representative investor in the global financial market will maximize her expected utility in terms of means and variancecovariance. The representative agent solves for her optimal portfolio composition of her financial capital in terms of the parameters of the model, such as its risk preferences. The optimization problem of the investor is:

$$
\max _{x} U=U\left(\bar{w}, \sigma_{w}^{2}\right)
$$

Using Equation (6), the functional form of a global investor's expected return on capital $(\bar{w})$ is given by:

$$
\bar{w}=(1+\delta) F+(R-\delta) x F
$$


with the corresponding variance of the return on capital given by:

$$
\sigma_{w}^{2}=F^{2}\left[(1-x)^{2} \sigma_{\delta}^{2}+x^{2} \sigma_{R}^{2}+2 x(1-x) \sigma_{\delta R}\right]
$$

where $R$ is the expected rate of return on capital to invest or the equilibrium rental rate of capital in the domestic commodity-dependent economy, and $\delta$ is the expected rate of return in the global market or the equilibrium rental rate of capital in the foreign economy. The parameter $\sigma_{\delta R}$ is the covariance between the two expected rates of return in our analysis. From the first order conditions of Equation (9), we get:

$$
x=\frac{(R-\delta)+\Phi\left(\sigma_{\delta}^{2}-\sigma_{\delta R}\right)}{\Phi \sigma}
$$

where $\Phi$ is the risk aversion coefficient or risk perception coefficient of the global investor and $\sigma=\sigma_{\delta}^{2}+\sigma_{R}^{2}+2 \sigma_{\delta R}$.

Based on Equation (12), the share of capital invested in the commodity exporting developing economy is increasing with the rate of return differentials and decreasing with the risk perception of global investors. Because $\lambda$ and $\theta$ in Equation (6) are strictly positive, the expected rate of return of capital in the financially constrained economy $(R)$ is always greater than $\delta$, (i.e., $R>\delta$ ).

For the aggregation of the behavior of the individual investor, we follow Magud et al., (2011) and rewrite Equation (12) as:

$$
x=\frac{R-\delta}{\Phi \sigma^{2}}+\alpha
$$

Equation (13) decomposes the share of capital invested in the commodity exporting economy into yield differential component and speculative component, where $\alpha=\left(\sigma_{\delta}^{2}-\sigma_{\delta R}\right) / \sigma^{2}$ is the share of investment to minimize the variance of the global investor's total expected rate of return.

Total demand for capital flows allocated to commodity-exporting developing economies of a global investor $j$ with wealth $W_{j}$ is given by $x_{j} W_{j}$, where $x_{j}$ is explained by Equation (13), or based on the behavior of individual investors. The total wealth of global investor, $\bar{w}$, is,

$$
\bar{W}=\sum_{j} W_{j}
$$

Let us denote $V^{*}$ as aggregate supply to invest in the commodity exporting developing economy. In equilibrium, the aggregate supply will equal the aggregate demand, and hence we get: 


$$
V^{*}=\sum_{j} x_{j} W_{j}
$$

Multiplying both sides of Equation (13) by $W_{j}$ and summing over $j$, we have:

$$
\sum_{j} x_{j} W_{j}=\left(\frac{R-\delta}{\sigma^{2}}\right) \sum_{j} \frac{W_{j}}{\Phi_{j}}+\alpha \sum_{j} W_{j}
$$

Substituting (14) and (15) in (16), we get:

$$
V^{*}=\left(\frac{\lambda \theta}{\sigma^{2}}\right) \sum_{j} \frac{W_{j}}{\Phi_{j}}+\alpha \bar{W}
$$

Equation (17) is the global investor's aggregate supply of capital flows to the commodity exporting developing economy. In the aggregate equilibrium, conditional on the aggregate risk perception of global investors, the commodity price has a positive effect on the share (supply) of capital flows to the commodity exporting economy. Commodity price has a positive effect on the global investor's capital flow supply to the commodity exporting developing economies, ceteris paribus. That is

$$
\frac{\delta V^{*}}{\partial p_{1}}=\frac{\delta V^{*}}{\partial \lambda} \cdot \frac{\delta \lambda}{\partial p_{1}}>0
$$

This hypothesis explains the role of commodity price in the portfolio allocation of global financial market investors to commodity-exporting economies. The commodity price is the global push factor of capital inflows to a commoditydependent economy.

\section{METHODOLOGY AND DATA}

To analyze the response of Indonesia's capital inflows to the commodity price and global financial market shocks, and to simultaneously show the effect of capital inflows (conditional on commodity price and global financial market shocks) on bank lending (financial resources allocation) in the Indonesian economy, we employ a Structural Vector AutoRegression (SVAR). The standard SVAR model is:

$$
B_{0} y_{t}=B_{1} y_{t-1}+\cdots+B_{p} y_{t-p}+\varepsilon_{t}
$$

where $y_{t}$ is a $(K \times 1)$ vector of random variables consisting of the global financial market fluctuation indicator, international commodity price index, nominal 
exchange rate, monetary policy rate, domestic liquidity, and bank lending in period $t ; B_{i}$ is a $(K \times K)$ parameter matrix and $i=1,2, \ldots, p . \varepsilon_{t}$ is a $(K \times 1)$ exogenous structural shock uncorrelated with the endogenous variables in the SVAR system and $E\left(\varepsilon_{t} \varepsilon_{t}{ }^{\prime}\right)=D$ is the variance- covariance matrix of structural shocks in the SVAR system. The contemporaneous effect between variables within the $y$ vector is explained by $B_{0^{\prime}}$ the matrix on the left-hand side of the SVAR equation system. The $B_{i}$ matrix on the right-hand side of the equation is the lag parameters of endogenous variables.

We restricted the commodity price and global financial market indicators to be strictly exogenous to the dynamics of capital inflows within the SVAR model. Our specification of the SVAR model consists of two strictly exogenous variables, gross capital inflows, and four domestic financial sector endogenous variables. Both strictly exogenous variables have a contemporaneous effect on Indonesian non-resident capital inflow (gross capital inflow). The domestic financial sector variables, i.e., the nominal exchange rate, domestic liquidity, and bank lending, respond to capital inflow shock. The specified empirical model allows for investigating the financial variables' response to capital inflow structural shocks, conditional on the effect of the strictly exogenous variables on capital inflow. Our SVAR system allows for monetary policy response to the nominal exchange rate, consistent with the empirical finding by Pontines and Siregar (2012) and Juhro et al. (2021).

In the first step of estimating the reduced form VAR, we put restrictions to ensure there is no feedback effect from the endogenous variables to the strictly exogenous variables. In the second step of recovering the structural parameters of the SVAR model, we put a restriction on the contemporaneous effect of the exogenous on endogenous. These restrictions are discussed in turn.

\section{A. SVAR Restriction: Contemporaneous Effect and Lag Structure}

The restriction on the SVAR for matrix $B_{0}$ can be seen in the Equation (19). The first restriction is on the international commodity price, which is assumed to be exogenous and to have a contemporaneous effect on the capital inflow, nominal exchange rate, and domestic liquidity, but not on monetary policy and bank lending. The global financial market fluctuation has a contemporaneous effect on the capital inflow, nominal exchange rate, and monetary policy rate, but not on liquidity and domestic bank loans (Prabheesh et al., 2020). Therefore, not all domestic variables respond contemporaneously to the exogenous variables in our empirical model specification in Equation (19).

$$
B_{0} Y_{t}=\left[\begin{array}{ccccccc}
1 & 0 & 0 & 0 & 0 & 0 & 0 \\
0 & 1 & 0 & 0 & 0 & 0 & 0 \\
b_{31}^{0} & b_{32}^{0} & 1 & 0 & 0 & 0 & 0 \\
b_{41}^{0} & b_{42}^{0} & b_{43}^{0} & 1 & 0 & 0 & 0 \\
0 & b_{52}^{0} & b_{53}^{0} & b_{54}^{0} & 1 & 0 & 0 \\
b_{61}^{0} & 0 & b_{63}^{0} & b_{64}^{0} & b_{65}^{0} & 1 & 0 \\
0 & 0 & b_{73}^{0} & 0 & 0 & b_{76}^{0} & 1
\end{array}\right]\left[\begin{array}{c}
\text { Comprice } \\
V X O_{t} \\
C F_{t}^{t o t a l} \\
E R_{t} \\
M P_{t} \\
L i q_{t} \\
C r_{t}^{j}
\end{array}\right]
$$


where $C F_{t}^{\text {total }}, E R_{t}, M P_{t}, L_{i q} q_{t} C r_{t}^{j}$, Comprice, and $V X O_{t}$ are, respectively, total gross capital inflow variables at time $t$ (measured by non-resident net capital flow, nominal exchange rate of Rupiah to US dollar or the price of one US dollar in rupiah), bank Indonesia's monetary policy rate, the ratio of M2 (broad money) to nominal GDP, bank lending as a ratio of GDP at time $t$, international commodity price (which is the weighted average of the commodity price index of Indonesian three largest export commodities, crude palm oil, liquid natural gas, and coal), and the proxy for global financial market fluctuation (which is the Chicago Board Options Exchange (CBOE) Volatility Index (VIX)). ${ }^{5,6}$

To elaborate on the effect of capital inflow shocks on bank lending, we estimate the above SVAR model using data on total bank lending, bank lending to the business sector, and bank lending to the non-business sector, as percentages of total GDP. Furthermore, we also decompose data on total bank lending to the business sector and estimate the models using data on bank lending to the primary commodity sector, to the secondary sector, and to the tertiary sector, as percentages of their respective sectoral GDP.

The total capital inflow in Equation (19) is assumed to have a contemporaneous effect on the nominal exchange rate, monetary policy rate, domestic liquidity, and bank lending measures. The nominal exchange rate has a contemporaneous effect on monetary policy and domestic liquidity but not on bank lending. The granger causality test results confirm the causal flow from the nominal exchange rate to monetary policy. Based on this test, we place monetary policy variables after the nominal exchange rate in the SVAR system. Both the nominal exchange rate and monetary policy variables are assumed to have no contemporaneous effect on bank lending.

The lag structure of the model is specified in the Equation (20). There is no restriction on the effect of all endogenous variables, but for the exogenous variables, we put restrictions on the feedback effect of all endogenous variables to international commodity price and global financial market condition.

$$
B_{i} Y_{t-p}=\left[\begin{array}{ccccccc}
b_{11}^{i} & 0 & 0 & 0 & 0 & 0 & 0 \\
0 & b_{22}^{i} & 0 & 0 & 0 & 0 & 0 \\
b_{31}^{i} & b_{32}^{i} & b_{33}^{i} & b_{34}^{i} & b_{35}^{i} & b_{36}^{i} & b_{37}^{i} \\
b_{41}^{i} & b_{42}^{i} & b_{43}^{i} & b_{44}^{i} & b_{45}^{i} & b_{46}^{i} & b_{47}^{i} \\
0 & b_{52}^{i} & b_{53}^{i} & b_{54}^{i} & b_{55}^{i} & b_{56}^{i} & b_{57}^{i} \\
b_{61}^{i} & 0 & b_{63}^{i} & b_{64}^{i} & b_{65}^{i} & b_{66}^{i} & b_{67}^{i} \\
0 & 0 & b_{73}^{i} & b_{74}^{i} & b_{75}^{i} & b_{76}^{i} & b_{77}^{i}
\end{array}\right]\left[\begin{array}{c}
\text { Comprice }_{t-p} \\
V X O_{t-p} \\
C F_{t-p}^{t o t a l} \\
E R_{t-p} \\
M P_{t-p} \\
L i q_{t-p} \\
C r_{t-p}^{j}
\end{array}\right]
$$

Next, we expand the model by decomposing the total capital inflows into debt and equity-based capital inflows. Davis (2015) found the effect of debt-based capital

\footnotetext{
Indonesia is a net exporter for the commodities included and weighted by the share of these commodities to total Indonesia export.

6 The VIX is the common measure of market fluctuation of stocks in the S\&P 500 index option in the literature (Andaiyani and Falianty, 2017; Rey, 2015).
} 
inflows to the domestic economy stronger than equity-based capital inflows. The restrictions are applied to the contemporaneous effect between the debt-based and the equity-based capital inflows, but not in the lag structure of both variables in the reduced form VAR estimation.

$$
\begin{aligned}
& B_{0} Y_{t}=\left[\begin{array}{cccccccc}
1 & 0 & 0 & 0 & 0 & 0 & 0 & 0 \\
0 & 1 & 0 & 0 & 0 & 0 & 0 & 0 \\
b_{31}^{0} & b_{32}^{0} & 1 & 0 & 0 & 0 & 0 & 0 \\
b_{41}^{0} & b_{42}^{0} & 0 & 1 & 0 & 0 & 0 & 0 \\
b_{51}^{0} & b_{52}^{0} & b_{53}^{0} & b_{54}^{0} & 1 & 0 & 0 & 0 \\
0 & b_{62}^{0} & b_{63}^{0} & b_{64}^{0} & b_{65}^{0} & 1 & 0 & 0 \\
b_{71}^{0} & 0 & b_{73}^{0} & b_{74}^{0} & b_{75}^{0} & b_{76}^{0} & 1 & 0 \\
0 & 0 & b_{83}^{0} & b_{84}^{0} & 0 & 0 & b_{87}^{0} & 1
\end{array}\right]\left[\begin{array}{c}
\text { omprice }_{t} \\
\text { VXO }_{t} \\
C F_{t}^{\text {equity }} \\
C F_{t}^{\text {debt }} \\
E R_{t} \\
M P_{t} \\
\operatorname{Liq}_{t} \\
C r_{t}^{j}
\end{array}\right] \\
& B_{i} Y_{t-p}=\left[\begin{array}{cccccccc}
b_{11}^{i} & 0 & 0 & 0 & 0 & 0 & 0 & 0 \\
0 & b_{22}^{i} & 0 & 0 & 0 & 0 & 0 & 0 \\
b_{31}^{i} & b_{32}^{i} & b_{33}^{i} & b_{34}^{i} & b_{35}^{i} & b_{36}^{i} & b_{37}^{i} & b_{38}^{i} \\
b_{41}^{i} & b_{42}^{i} & b_{43}^{i} & b_{44}^{i} & b_{45}^{i} & b_{46}^{i} & b_{47}^{i} & b_{48}^{i} \\
b_{51}^{i} & b_{52}^{i} & b_{53}^{i} & b_{54}^{i} & b_{55}^{i} & b_{56}^{i} & b_{57}^{i} & b_{58}^{i} \\
0 & b_{62}^{i} & b_{63}^{i} & b_{64}^{i} & b_{65}^{i} & b_{66}^{i} & b_{67}^{i} & b_{68}^{i} \\
b_{71}^{i} & 0 & b_{73}^{i} & b_{74}^{i} & b_{75}^{i} & b_{76}^{i} & b_{77}^{i} & b_{78}^{i} \\
0 & 0 & b_{83}^{i} & b_{84}^{i} & b_{85}^{i} & b_{86}^{i} & b_{87}^{i} & b_{88}^{i}
\end{array}\right]\left[\begin{array}{c}
\text { Comprice } \\
\text { VXO }_{t} \\
C F_{t}^{\text {equity }} \\
C F_{t}^{\text {debt }} \\
E R_{t} \\
M P_{t} \\
\operatorname{Liq}_{t} \\
C_{t}^{j}
\end{array}\right]
\end{aligned}
$$

\section{B. Data}

We use the longest available quarterly data on Indonesia's GDP and balance of payment. The available data starts from the first quarter of 1993 up to the third quarter of 2018. The data is from various sources, namely VIX/VXO from Datastream, commodity price index from the IMF, Indonesia's commodity export revenue from UN COMTRADE, and the remaining data are from Bank Indonesia and Indonesian Statistical Bureau (BPS). Appendix details the data used in our analysis, while Table 1 reports the descriptive statistics of the data.

Table 1.

\section{Descriptive Statistics}

The table shows the descriptive statistics of each variable as explained in the data Appendix. The data series for each variable is gathered from three main sources, Indonesian Statistical Bureau (BPS), Bank Indonesia (BI), and IMF. The period of the data is from the first quarter of 1993 to the third quarter of 2018.

\begin{tabular}{lccccc}
\hline Variables & Mean & Median & Max & Min & Std. Dev. \\
\hline Commodity Price & 108.79 & 99.37 & 239.56 & 37.57 & 58.32 \\
Total Capital Inflow & 3569.14 & 2121.79 & 18386.84 & -10598.62 & 5381.26 \\
Debt Based Capital Inflow & 1460.10 & 845 & 12123.99 & -9274.40 & 3630.27 \\
Equity Based Capital Inflow & 2109.05 & 1398 & 7138.04 & -9865.62 & 2211.38 \\
Total Bank Lending & 128.95 & 115.6728 & 281.17 & 74.99 & 44.16 \\
Bank Lending to Non-Business Sector & 26.80 & 25.85 & 41.55 & 9.59 & 9.51 \\
\hline
\end{tabular}


Table 1.

Descriptive Statistics (Continued)

\begin{tabular}{lccccc}
\hline Variables & Mean & Median & Max & Min & Std. Dev. \\
\hline Bank Lending to Business Sector & 102.16 & 82.43 & 264.28 & 56.93 & 45.52 \\
Bank Lending to Primary Sector & 42.81 & 40.63 & 80.07 & 22.99 & 14.69 \\
Bank Lending to Secondary Sector & 105.06 & 89.16 & 350.15 & 44.60 & 53.61 \\
Bank Lending to Tertiary Sector & 139.43 & 116.10 & 355.52 & 66.51 & 68.05 \\
Nominal Exchange Rate & 8439.85 & 9132.70 & 14684.30 & 2008.30 & 3709.03 \\
Liquidity & 175.53 & 161.27 & 253.93 & 133.94 & 30.37 \\
Monetary Policy Rate & 11.63 & 8.82 & 63.99 & 4.25 & 9.16 \\
VXO & 19.48 & 16.89 & 61.88 & 8.64 & 8.20 \\
\hline
\end{tabular}

\section{EMPIRICAL RESULTS}

The estimation results based on our specified SVAR models have 2 optimum lags. Besides, the autoregressive characteristic roots of all variables in the reduced form VAR system are less than 1 indicating the stability of the VAR system. The specified restriction for structural shocks is overidentified and statistically significant and hence the estimated SVAR models are statistically valid for further analysis.

\section{A. The Response of Capital Inflows to International Commodity Price and Global Financial Market Shocks}

Figure 1 shows the estimated Impulse Response Function (IRF) of the total gross capital inflow (CF_TOT) due to innovations in international commodity price (Shock 1) and the global financial market fluctuation (Shock 2).

\section{Figure 1.}

\section{Response of Indonesian Gross Capital Inflows to Exogenous External Shocks}

The figure plots the estimated impulse response functions (IRFs) of total capital inflows (CF_TOT) to structural VAR innovation \pm 2 standard error from a commodity price shock (shock 1 ) and a global financial market fluctuation (shock 2). Global financial market fluctuation is measured using VIX index data; a positive shock means an increase in the global market volatility. The impulse response functions are plotted up to 24 quarters after the exogenous structural shocks and are based on the model without decomposed the capital inflow components. The IRFs were estimated using the SVAR model employing Indonesian quarterly data from q1 1993 to q3 2018.

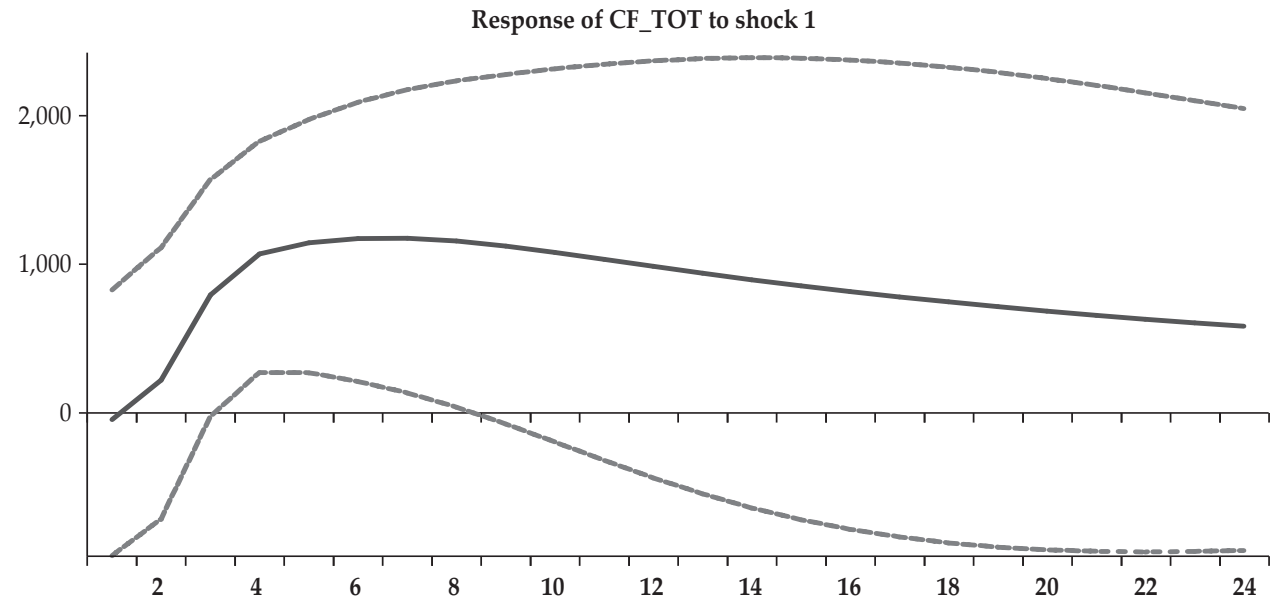


Figure 1.

Response of Indonesian Gross Capital Inflows to Exogenous External Shocks (Continued)

Response of CF_TOT to shock 2

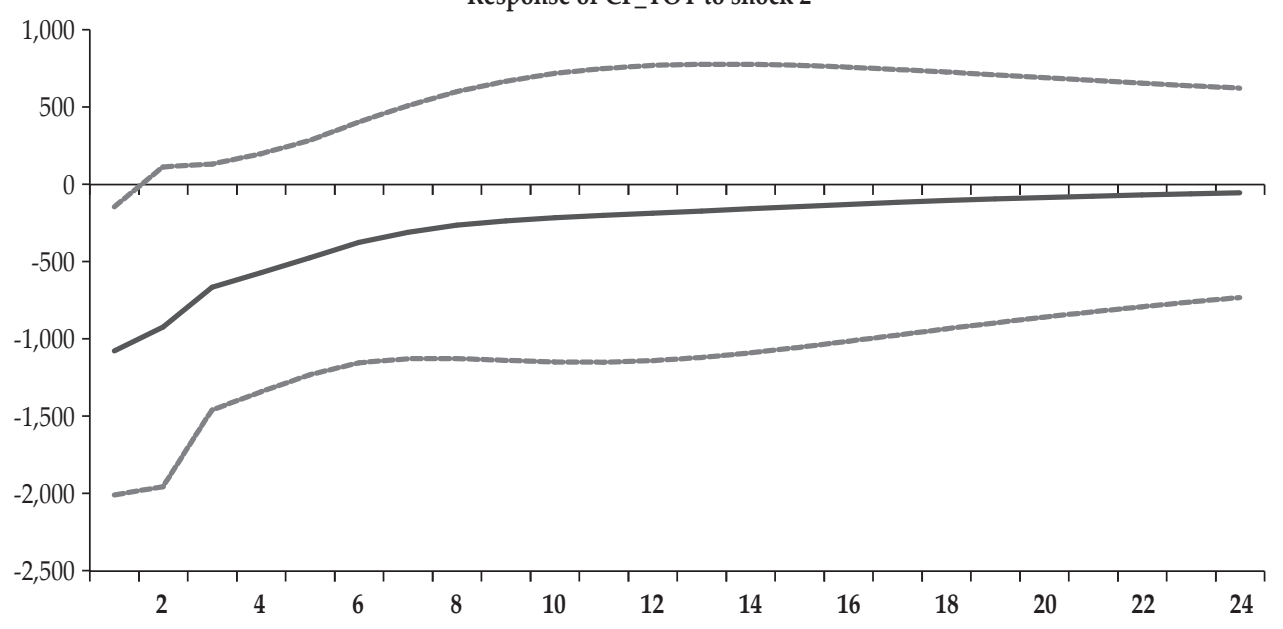

The IRFs in Figure 1 suggest that total capital inflows do not respond instantaneously to commodity price shocks. In the first quarter, the response of total capital inflow to the commodity price shock is almost zero, whereas total capital inflow increases sharply during the second to fifth quarter and remains above the baseline but with slow decay after its peak. On the contrary, the global financial market shock has an immediate positive effect on the total capital inflow right from the first quarter. Total capital inflow decreases sharply within five quarters to its long run level, following the global financial market shock. The close relation between commodity price and capital flows is also found in Reinhart et al. (2016) and Byrne and Fiess (2016).

Secondly, the estimated IRFs show that global financial market fluctuations play an important role in capital inflows to Indonesia, but only in the short run. The immediate response of capital inflows to global financial market fluctuations confirms the finding of Forbes and Warnock (2012) and Rey (2015). The short-run response of capital inflows to global financial market shocks shown in Figure 1 is also documented by Cerutti et al. (2019).

These two findings suggest that the negative shocks from commodity prices and global financial market fluctuations are the most potent source of capital inflow stops and reversals in the Indonesian economy. The episodes of commodity price bust in the fourth quarter of 2012 and the negative global financial market shock, the tapering off in May 2013, are a recent example of this situation. On the contrary, a stable global financial market during a commodity price boom would most likely induce an overheating of the domestic economy (Davis and Presno, 2014; Unsal, 2013).

We also further decompose the total capital inflows into the debt-based and the equity-based capital inflows. Figure 2 present the estimates. The equity-based capital inflows immediately respond by increasing within the first three quarters of a commodity price shock. On the contrary, the equity-based capital inflows 
immediately respond to a global financial market fluctuation shock by decreasing within the first three quarters of the shock. The commodity price shock effect on the equity-based inflows is highly persistent, in contrast to the global financial market fluctuation shock effect. The quick responses of equity-based capital inflows make empirical sense because Indonesia has a significant share of foreign investors in its stock market. According to Azis and Shin (2015), global investors' behavior is sensitive to the deterioration of in global factors, typically prone to buying the rumor and selling the news. This explains the equity market's quick response to a global shock. Concerning the Indonesian case, the foreign interest rate increase (a global liquidity deterioration) immediately spurs capital outflows and causes the rupiah to depreciate (Agung et al., 2016). Based on the portfolio choice theory, the commodity price shock affects the global investor's risk perception of asset prices. The commodity price increase would also increase the revenue stream of a commodity-exporter economy and thus their asset prices. A commodity price increase would alter investors' expected return on domestic financial assets and induce capital inflows to a commodity-dependent economy. Based on our result, both commodity price and global financial market shocks would affect the equitybased capital inflows to a commodity dependent economy.

Figure 2.

\section{Response of Indonesian Debt-based and Equity-based Capital Inflows to Exogenous External Shocks}

The figure plots the IRFs of equity-based total capital inflows (CF_EQUITY) and debt-based capital inflows (CF_ DEBT) to structural VAR innovation \pm 2 standard error from a commodity price (shock 1 ) and a global financial market fluctuation (shock 2). Global financial market fluctuation is measured using VIX index data; a positive shock means an increase in the global market volatility. The impulse response functions are plotted up to 24 quarters after the exogenous structural shock and based on the model with decomposed the capital inflow components. The IRFs were estimated using the SVAR model employing Indonesian quarterly data from q1 1993 to q3 2018.

\section{Response to Structural VAR Innovations \pm 2 S.E.}

Response of CF_EQUITY to Shock1

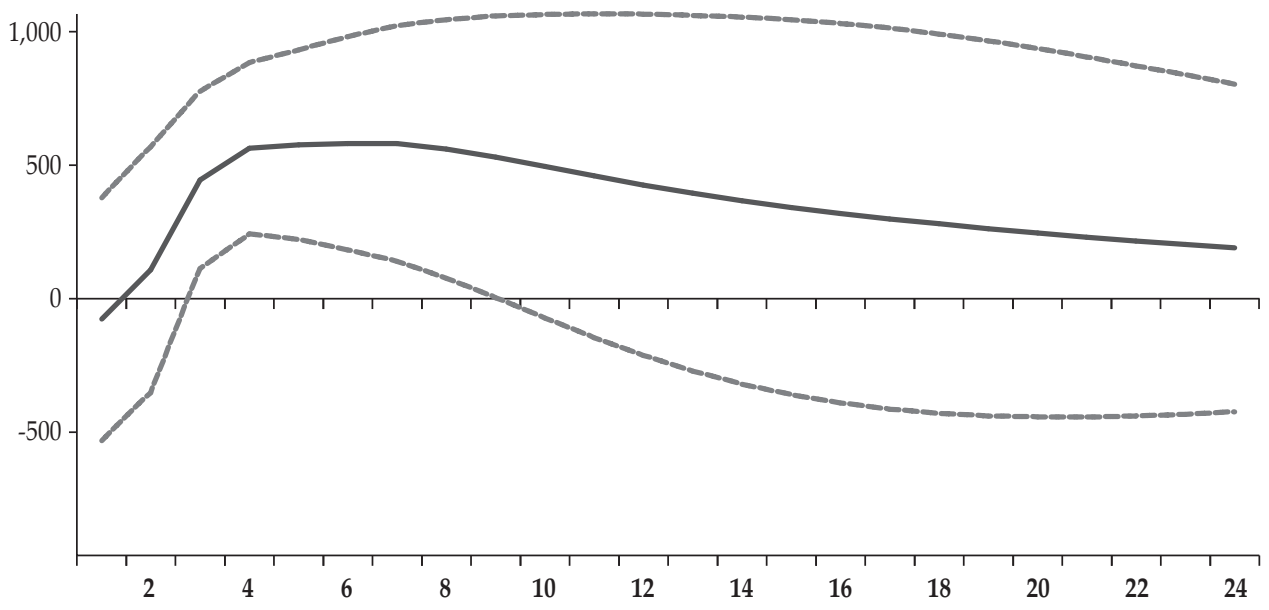


Figure 2.

Response of Indonesian Debt-based and Equity-based Capital Inflows to Exogenous External Shocks (Continued)

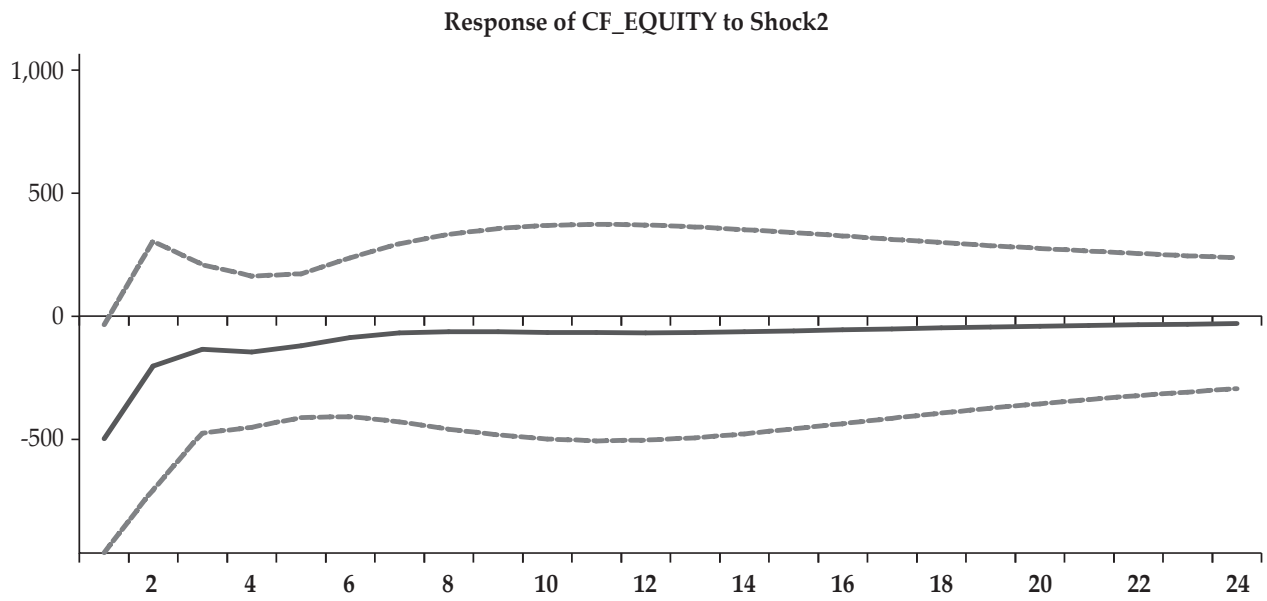

Response of CF_DEBT to Shock1

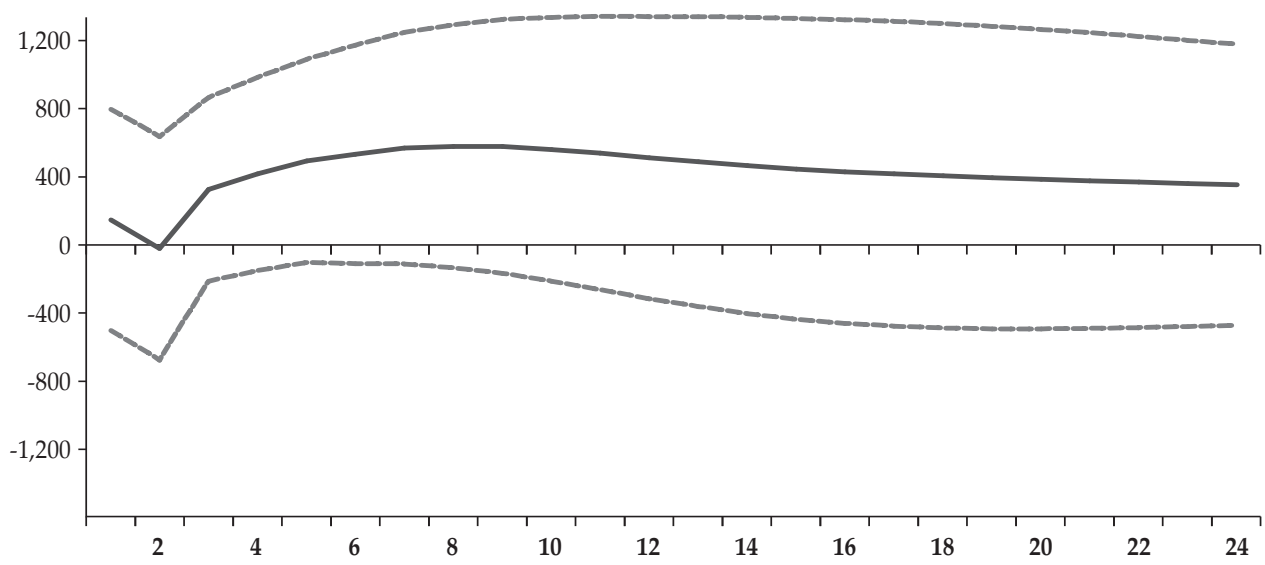

Response of CF_DEBT to Shock2

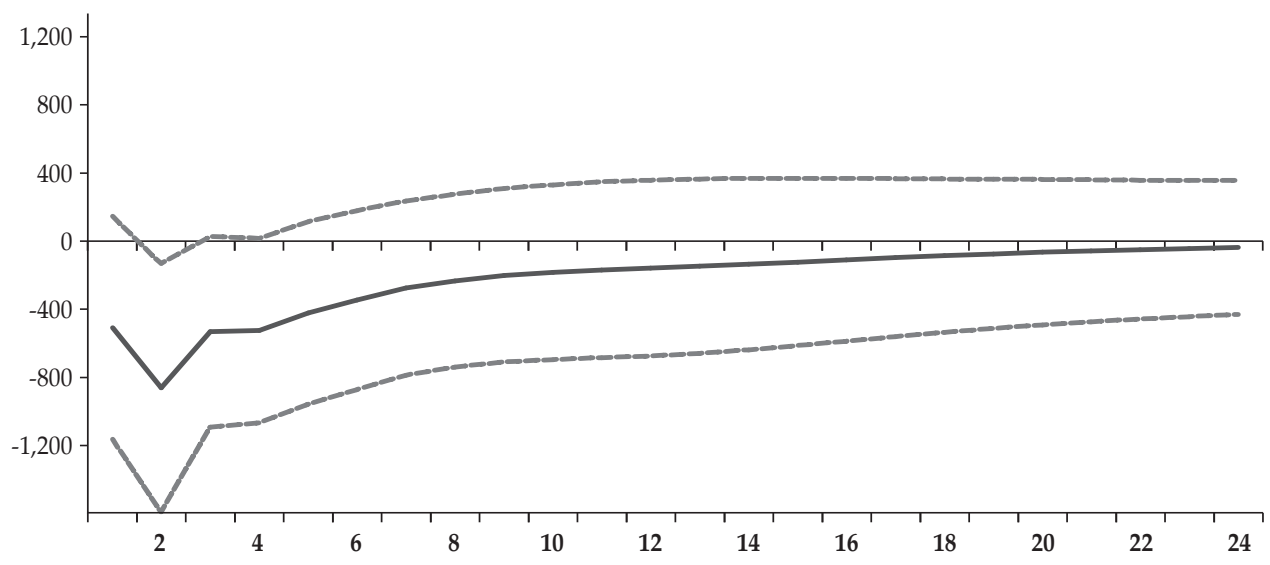


The debt-based capital inflows' immediate response to a commodity price shock is positive in the first quarter and then decline for three quarters before bouncing back. In response to a positive global financial market fluctuation shock, the debt-based capital inflows reduce. The magnitude of the response is relatively stronger compared to commodity price shocks, though the commodity price shock effect is more persistent. Following the global financial crisis in 2008, the capital inflows into emerging markets cause credit to grow through corporate bond issuance by nonfinancial borrowers (Azis and Shin, 2015). With low global interest rates due to quantitative easing policies in advance countries, there was an increase in the issuance of government and corporate securities in emerging countries' domestic bonds markets. Governments in emerging countries used the low cost of debt financing opportunities to increase their local currency bond issuance (Mehrotra et al., 2012). Furthermore, the share of foreign ownership in the local currency bond markets and bank holdings of sovereign bonds rose.

Sahay et al. (2014) show that half of all global capital flows entered emerging economies during 2009-2012, with $75 \%$ of these gross inflows to emerging economies received by just eight countries (Brazil, China, India, Indonesia, Mexico, Peru, Poland, and Turkey). Throughout the 2010-2012 period, Indonesia gained large capital inflows induced by both global excess liquidity (with investors searching for higher yield) and Indonesia's promising economic conditions due to high commodity-export prices (Warjiyo, 2016, 2014). The taper tantrum effect on a commodity-dependent emerging economy's capital flows is higher as compared to other emerging economies. According to Basri (2017), India performed better than Indonesia after the taper tantrum in terms of economic growth, current account deficits, and financial sector stability. Both countries have similar levels of financial and economic development. Moreover, they also have fundamental differences, particularly, in their economic structures. Indonesia's main export products are commodities and processed raw materials, India's exports are concentrated in the service sector, particularly, in software development and business process outsourcing (Nehru, 2013). Indonesia's experience in May 2013 is a clear illustration of the combined shock from global factors to a commoditydependent economy. The commodity price decrease in the fourth quarter of 2012 followed by the tapering off policy announcements in the US in May 2013, complicates Indonesia's monetary policy response to the global shocks.

What we can infer from the capital inflow decomposition above is that first, the response of capital inflows due to the commodity price shock is characterized by a hump shape pattern, and with a delay response. This effect is robust across the use of total capital inflows and its decomposition into debt- and equity-based inflows. Secondly, a positive (an increase in volatility) global financial market shock leads to an instantaneous decline in capital inflows. The decline of the debt-based capital inflows is slower than the equity-based capital inflows. A commodity price shock has a different impact on capital flows as compared with a global financial market shock. A commodity price shock leads to an increase (decrease) in a commodity-dependent economy's income (Fornero and Kirchner, 2018), and thus increases domestic investment demand. In contrast, a global financial market shock induces capital inflows, which is not followed by a real investment increase in domestic economy. Davis (2014) shows that international debt-based 
flows have a different effect on the international business cycle co-movement as compared with international equity-based flows. In his paper, Davis (2014) explains by contrasting some theoretical work that emphasizes cross-country financial accelerators through the balance sheets of financial intermediaries with the results from models in the international real business cycle literature that do not contain a role for balance sheet effects. He found a much different effect of cross-border financial integration. Davis (2014) argues that debt-based flows are more likely to involve balance sheets, particularly, the balance sheets of financial intermediaries, and thus involve these cross-border financial accelerators. Debtbased capital inflows directly involve the balance sheets of financial intermediaries and thus lead to domestic financial accelerator effects that equity-based capital inflows do not. Also, the commodity price involves financial accelerators due to the higher financial intermediaries' asset prices and lower leverage constraints. A similar mechanism is probably at work in our research. This possibly could explain our empirical finding that the commodity price has a more persistent effect, whereas the debt-based capital inflow has a slower but more persistent response to exogenous shocks compared to the equity-based inflow.

We now turn to the standard forecast error variance decomposition to further examine the relative importance of the commodity price shock versus the global financial market shock in explaining the capital inflows in Indonesia. Table 2 presents the estimates from the variance error decomposition of the total capital inflows. These estimates show the percentage contribution of the commodity price and global financial market shocks on the variation of total capital inflows. It is clear that the commodity price shock only explains less than one percent of the variation in capital inflows during the first quarter after the shock. However, over a longer period, the commodity price shock becomes more important. At the end of the second year after the shock, more than 30 percent of the variation in the dynamics of capital inflows is explained by the commodity price shock. In the first quarter, approximately 8.9 percent of the variation in capital inflows are explained by the global financial market shock. This increased throughout the first four quarters up to 16.1 percent before decreasing over a longer time horizon (see Table 2).

Table 2 .

\section{Variance Decomposition of Total Capital Inflows}

The table shows the forecast error variance decomposition of total capital inflows from the SVAR factors for 24 quarters ahead. The estimated variance decomposition is based on the SVAR model without decomposing the capital inflow components into debt-based and equity-based capital inflows. The SVAR model was estimated using Indonesian quarterly data from q1 1993 to q3 2018.

\begin{tabular}{lcc}
\hline $\begin{array}{l}\text { Period } \\
\text { (quarter) }\end{array}$ & Commodity Price Shock (\%) & $\begin{array}{c}\text { Global Financial Market Fluctuation } \\
\text { Shock (\%) }\end{array}$ \\
\hline 1 & 0.01620 & 8.94074 \\
4 & 10.5388 & 16.0562 \\
8 & 30.7135 & 14.0795 \\
12 & 41.0332 & 12.2446 \\
16 & 46.4403 & 11.2552 \\
20 & 49.6621 & 10.6289 \\
24 & 51.7429 & 10.2018 \\
\hline
\end{tabular}


According to the above findings, both of external shocks play important roles in explaining Indonesia's capital inflow variation. In the first four quarters, more than 26 percent of the capital inflow variation is explained by these two exogenous shocks. The global financial market shock has only a short-run effect on capital inflows to Indonesia. Therefore, capital inflows induced by the global financial market shock in Indonesia tend rely on short-run financial portfolio instruments. Several studies have found that movements in the $\mathrm{VXO}$, which is widely seen as a market proxy for risk aversion and uncertainty, are strongly associated with capital flows. Forbes and Warnock (2012) and Bruno and Shin (2015) emphasize the surge in capital flows associated with the lowering of the VIX/VXO. Bruno and Shin (2015) found US monetary policy and global liquidity are intimately linked. This finding is supported by Rey (2015), who documented that an increase in the US monetary policy rate leads to an increase in VXO or global market volatility. According to Rey (2013), the carry trade literature suggests that carry trade flows tend to increase when the VXO is low and falls when the VXO is high. Hot money outflows from the center country are typically financed by banks that lend to carry traders (speculators), who borrow in low interest-rate currencies to invest in high interest-rate currencies or currencies expected to appreciate (McKinnon, 2014). This explains the important effect of VXO on capital inflows to Indonesia throughout the quantitative easing policy implementation by advanced economies following the global financial crisis in 2008. The surges of capital inflows during that period caused the emerging economies' financial sector stability vulnerable to the capital inflow reversal.

In general, our results confirm the results of Byrne and Fiess (2016), Cerutti et al. (2019), and Daviset al. (2019) on the small importance of the global financial cycle and the center country's monetary policy as the external push factors of capital inflows. The center country's monetary policy, like US monetary policy, which operates through the short-term interest rate, and the global financial market fluctuation have a relatively small effect on the capital inflows to emerging economies (Byrne and Fiess, 2016). Specifically, for Indonesia, an emerging commodity-dependent economy, the commodity price plays an important role as a global factor of capital inflows. Furthermore, we found the importance of the global factors to debt-based capital inflows to Indonesia, consistent with Davis (2015), who found the changes in macroeconomic and financial variables result from the debt-based inflow changes, but not from the equity-based inflow changes. We observed the debt-based capital inflows have more persistent response to a commodity price shock compared to the global financial market shock. This suggests the commodity price shock plays an important role in shaping the domestic macroeconomic and financial variables' fluctuations through the persistent response of the debt-based capital inflows to the Indonesian economy.

The capital inflows induced by a positive commodity price shock is persistent and would have a stronger effect on the Indonesian financial resource allocation through bank lending. This highlights the importance of the sources of the shocks and the transmission of the commodity price shock to the Indonesian real sector, which is the second focus of our research. 
B. Response to Capital Inflow Shock

Next, we elaborate the domestic endogenous variables' response to capital inflow shock (Shock 3), conditional on exogenous external factors. The IRFs of the first three variables, namely the nominal exchange rate (ER), monetary policy rate (MONPOL), economic liquidity (LIQ_M2), to the capital inflow shock can be seen in Figure 3, whereas the IRFs of bank lending allocation across economic sectors can be seen in Figure 4. The IRFs in Figure 3 show that the nominal exchange rate appreciates, and the monetary policy rate decreases immediately up to three quarter after the gross capital inflow shock. Furthermore, we observed no clear pattern of liquidity response (measured as M2 to GDP ratio) to the gross capital inflow shock.

Figure 3.

\section{Response of Nominal Exchange Rate, Monetary Policy Rate and Liquidity to Gross Capital Inflows}

The figure plots the IRF of the nominal exchange rate (ER) in the first panel, monetary policy rate (MONPOL) in the second panel, and Liquidity (LIQ_M2) to structural VAR innovation \pm 2 standard error from the total capital inflow shock (shock 3 ). The exchange rate is in the Rupiah price of 1 US dollar, a lower price means exchange rate appreciation in absolute value; the monetary policy rate is in percentage and liquidity also in percentage of M2 (broad money) to nominal GDP. The IRFs were estimated using the SVAR model employing Indonesian quarterly data from q1 1993 to q3 2018.

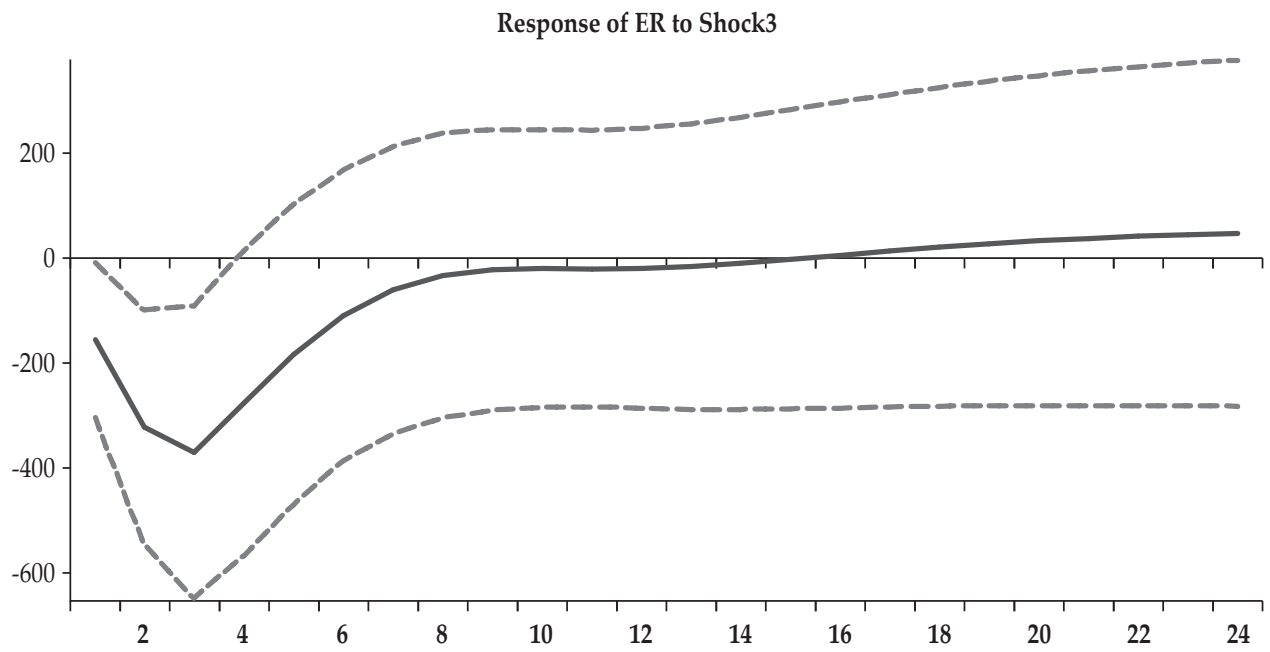


Figure 3.

Response of Nominal Exchange Rate, Monetary Policy Rate and Liquidity to Gross Capital Inflows (Continued)

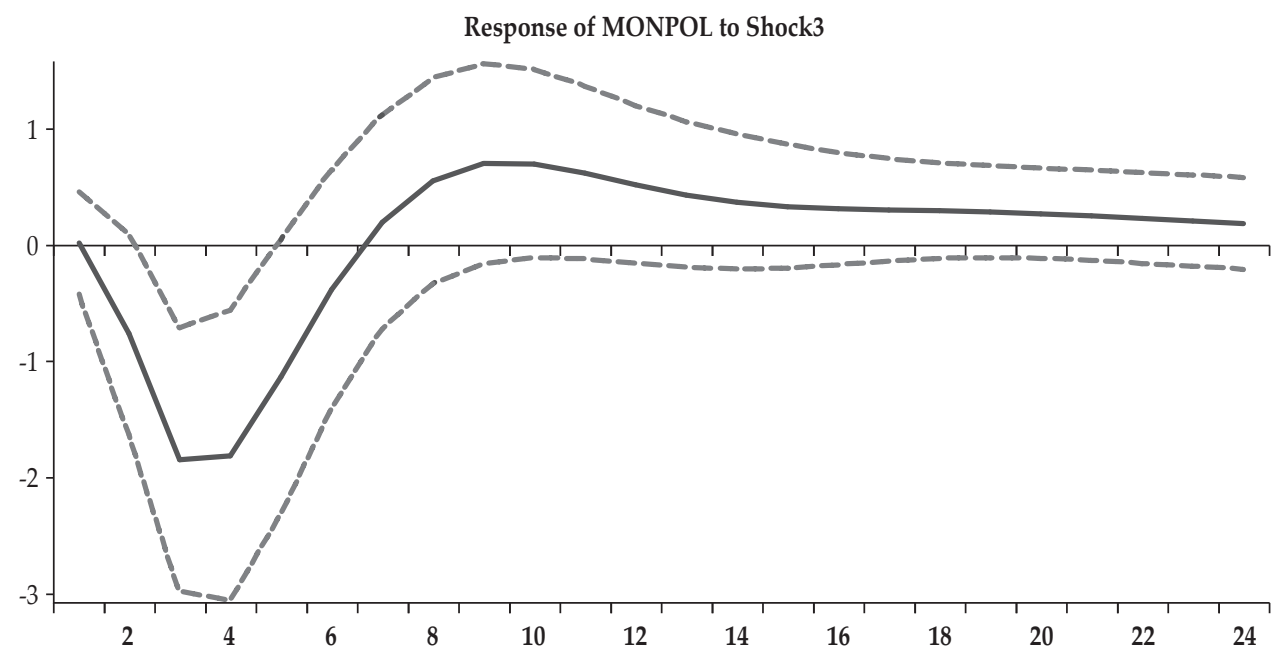

Response of LIQ_M2 to Shock3

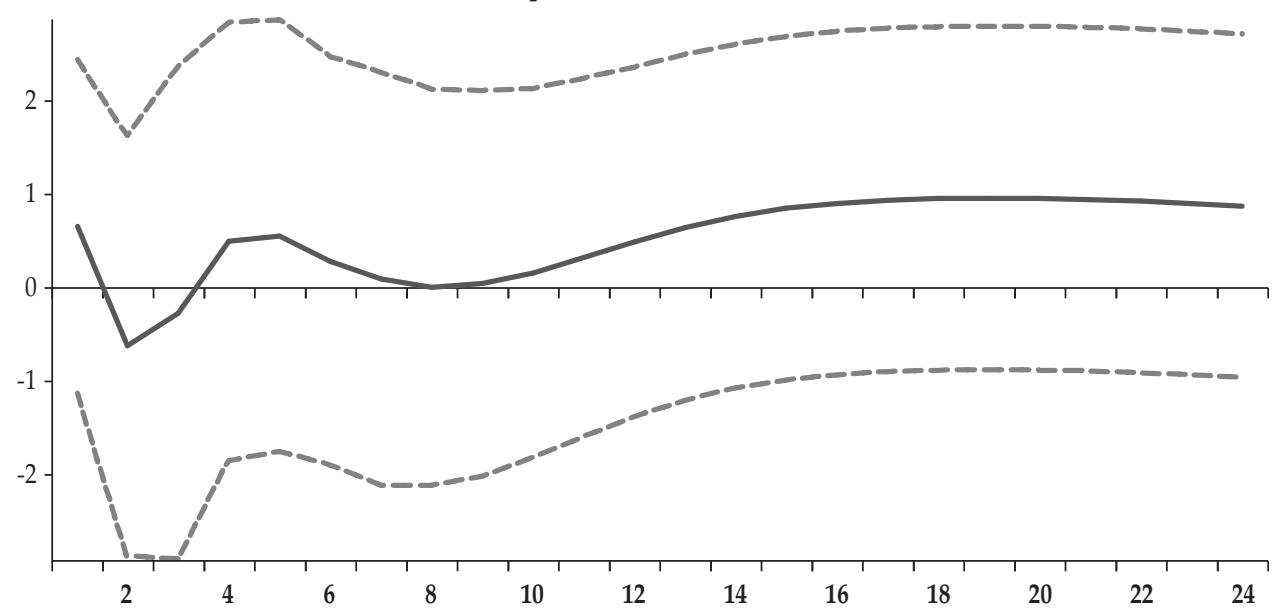

The nominal exchange rate appreciation and the decrease in the monetary policy rate in response to the capital inflow shock require no further interpretation. These responses are consistent with the empirical literature. The duration pattern of the monetary policy rate's response is very similar to the nominal exchange rate's response, which implies Indonesia's monetary policy is closely related to the nominal exchange rate (Pontines and Siregar, 2012). The Indonesian economy's liquidity response to capital flow shocks has no clear pattern. The result shows that a decrease in monetary policy rate in response to a capital inflow shock was combined with other monetary policy instruments to maintain stable liquidity stock. Liquidity expansion following a relaxation of monetary policy could increase 
the inflation rate. To overcome this issue, the effects of a decrease in monetary policy rate on liquidity should be offset by changes in the other monetary policy instruments, such as the sterilization policy (Warjiyo, 2013, 2017).

The first row of Figure 4 shows a decrease in total bank lending to all economic sectors and the business sector during the first two quarters in response to a capital inflow shock. From the third up to the eighth quarter after the shock, bank lending significantly increases. In contrast, the bank lending to non-business sector responds to the capital inflow shock by increasing right from the first quarter after the shock and declines after the eighth quarter.

Figure 4.

\section{Response of Bank Lending by Economic Sectors to Total Gross Capital Inflows}

The figure plots the IRFs of bank lending to structural VAR innovation \pm 2 standard error from total capital inflow shock (shock 3). The first row shows IRFs of total bank lending (CR_GT), bank lending to the business sector (CR_ TOT), and bank lending to the non-business sector (CR_NLU). The second row plots IRFs of bank lending to the business sector (CR_TOT) decomposed by the economic sectors, namely, the bank lending to the primary sector (CR_ PRIM), secondary (CR_SEK), and tertiary sector (CR_TER). The IRF was estimated using the SVAR model employing Indonesian quarterly data from q1 1993 to q3 2018. Note that bank lending in all cases is scaled by nominal GDP.

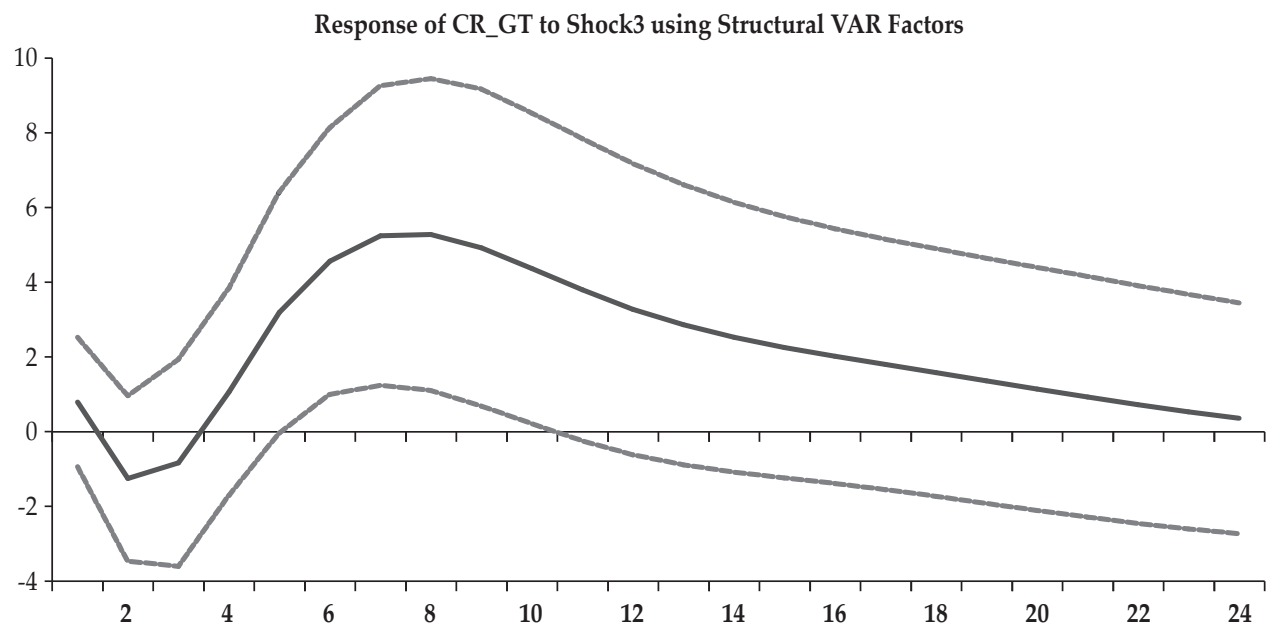

Response of CR_TOT to Shock3 using Structural VAR Factors

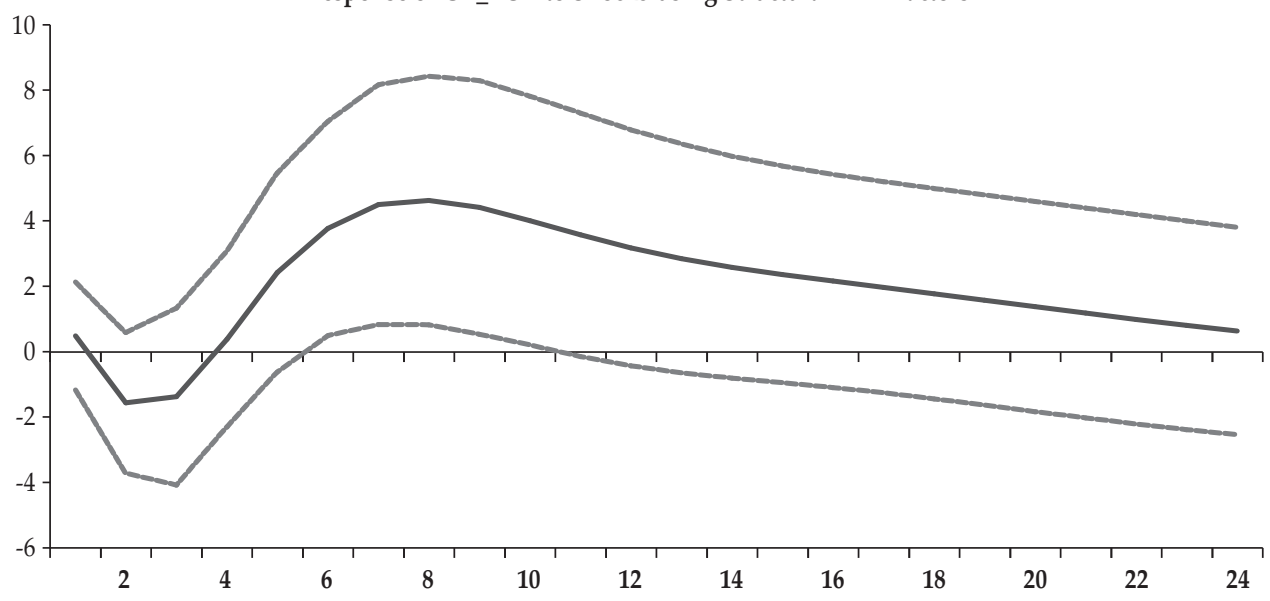


Figure 4. Response of Bank Lending by Economic Sectors to Total Gross Capital Inflows
(Continued)
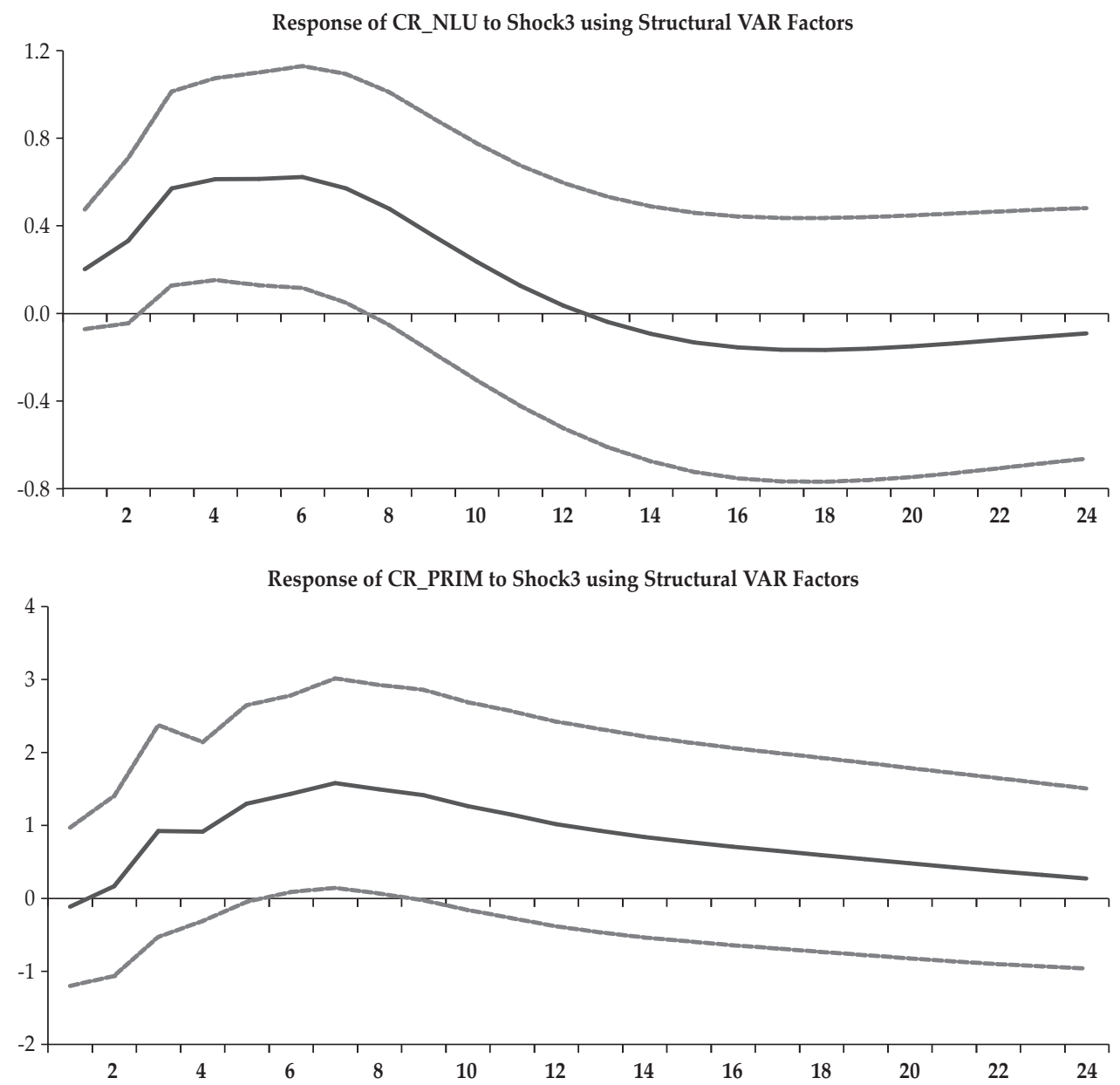

Response of CR_SEK to Shock3 using Structural VAR Factors

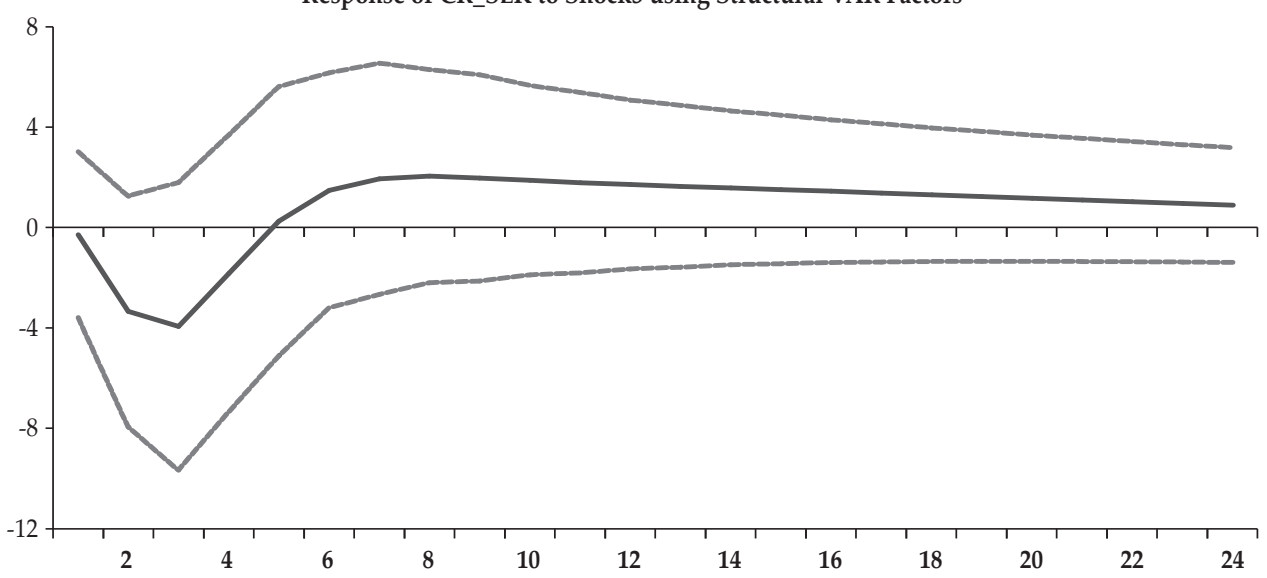


Figure 4.

Response of Bank Lending by Economic Sectors to Total Gross Capital Inflows (Continued)

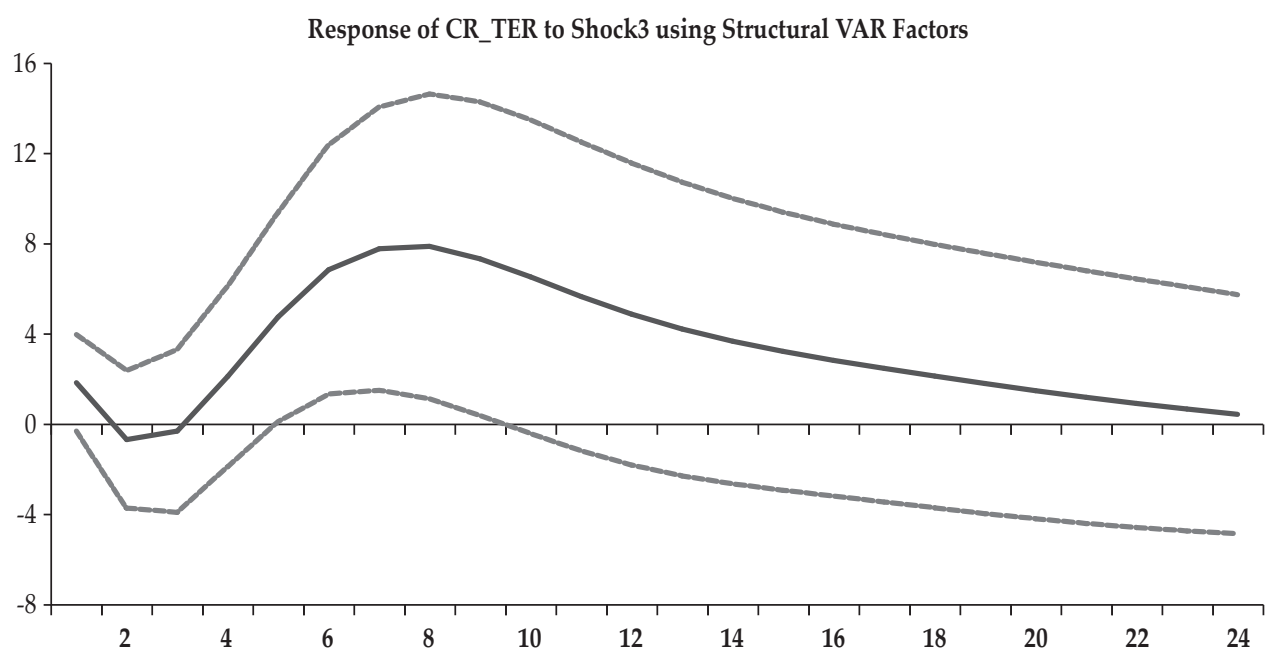

In the second row of Figure 4, the bank lending to the primary sector (CR_ PRIM) responds to the capital inflow shock by increasing. The other two sectors respond to the capital inflow shock by decreasing for the first two quarters and increasing in the third quarter. Based on these findings, the secondary sector (manufacturing and infrastructure) benefited least from the increase in bank lending induced by the capital inflow shock. Capital inflows to the Indonesian economy induced bank lending growth in all but the secondary sector. ${ }^{7}$ The Capital inflows to the Indonesian economy changes the allocation of the bank lending to the non-business sector, and within the business sector, it reallocates lending from the secondary sector to the primary and tertiary sectors. There is evidence of the financial Dutch disease (Benigno and Fornaro, 2014; Botta, 2015), as the bank lending allocation to the non-business sector and commodity sector expanded during the periods of commodity price boom.

After the Asian financial crisis in 1998, the global economy was characterized by the commodity price boom (Reinhart et al., 2016). Balakrishnan et al. (2013) also found the short-term debt portfolios were used as a substitute for long-run financing instruments in emerging Asian economies. Our research shows the allocation of the financial resources goes hand in hand with the capital inflows induced by the commodity price shock and global financial market fluctuations. This type of capital inflows reallocates bank lending to the unproductive nonbusiness sector dominated by household consumption loans.

With the current structure of the financial system and capital mobility policy regime, Indonesia needs a capital flows management policy concerning

\footnotetext{
7 We use the ratio of bank lending to GDP data, the increase in this ratio means the bank lending increase faster than the GDP. The increases in this ratio also indicate there is an excess supply of bank loans relative to loan demand (GDP).
} 
commodity price fluctuation. The combination of capital account openness and financial system structure makes the Indonesian financial system vulnerable to global factor shocks. The implication of our finding is that capital inflows to the commodity-dependent economy would always be highly volatile as long as the international commodity price is highly volatile. It would depress the domestic economy's productive manufacturing sector because of bank lending reallocation to the primary commodity sector.

In periods of high capital inflows, the financial sector expansion leads to excessive risk-taking by banks, which has been known as the source of financial instability (Acharya and Naqvi, 2012; Hahm et al., 2013; Korinek and Sandri, 2016). In the Indonesian case, Satria and Juhro (2011) found risk perception of the banking sector plays an important role in the risk-taking channel of monetary policy transmission. The monetary policy would be ineffective to stabilize the economy. The risk perception of banks and other institutions in the financial sector weakens the effect of a monetary policy stance. The macroprudential policy mixed with capital flow management policy could be the solution to macroeconomic stabilization (Korinek and Sandri, 2016), but with additional emphasis on economic sector heterogeneity response.

\section{ROBUSTNESS CHECK RESULTS}

In addition to decomposing the total capital flows into debt-based and equitybased flows, we also use an alternative method to check the consistency of the results. Using the SVAR model, the response of capital inflows measures to exogenous commodity price and global financial market shocks can be calculated but not the significance of the partial effect of both exogenous variables to capital inflow measures. In addition to the SVAR model, we also estimate a VARX model (see Pesaran, 2015) with restrictions on the effect of the exogenous variables on the domestic economy variables other than the capital inflows. Based on the estimates of the VARX model, commodity price has a significant effect on total capital inflows within all model specifications, but not the global financial market fluctuation (Table 3). The effect of the commodity price on debt-based and equitybased capital inflows is significant, whereas the effect of the global financial market fluctuation is only statistically significant to debt-based capital inflows (Table 4). Based on our VARX model, a significant long-run effect of commodity price on capital inflows is robust. In contrast, global financial market fluctuation only has a significant effect on the debt-based capital inflows but not on total and equitybased capital inflows. 


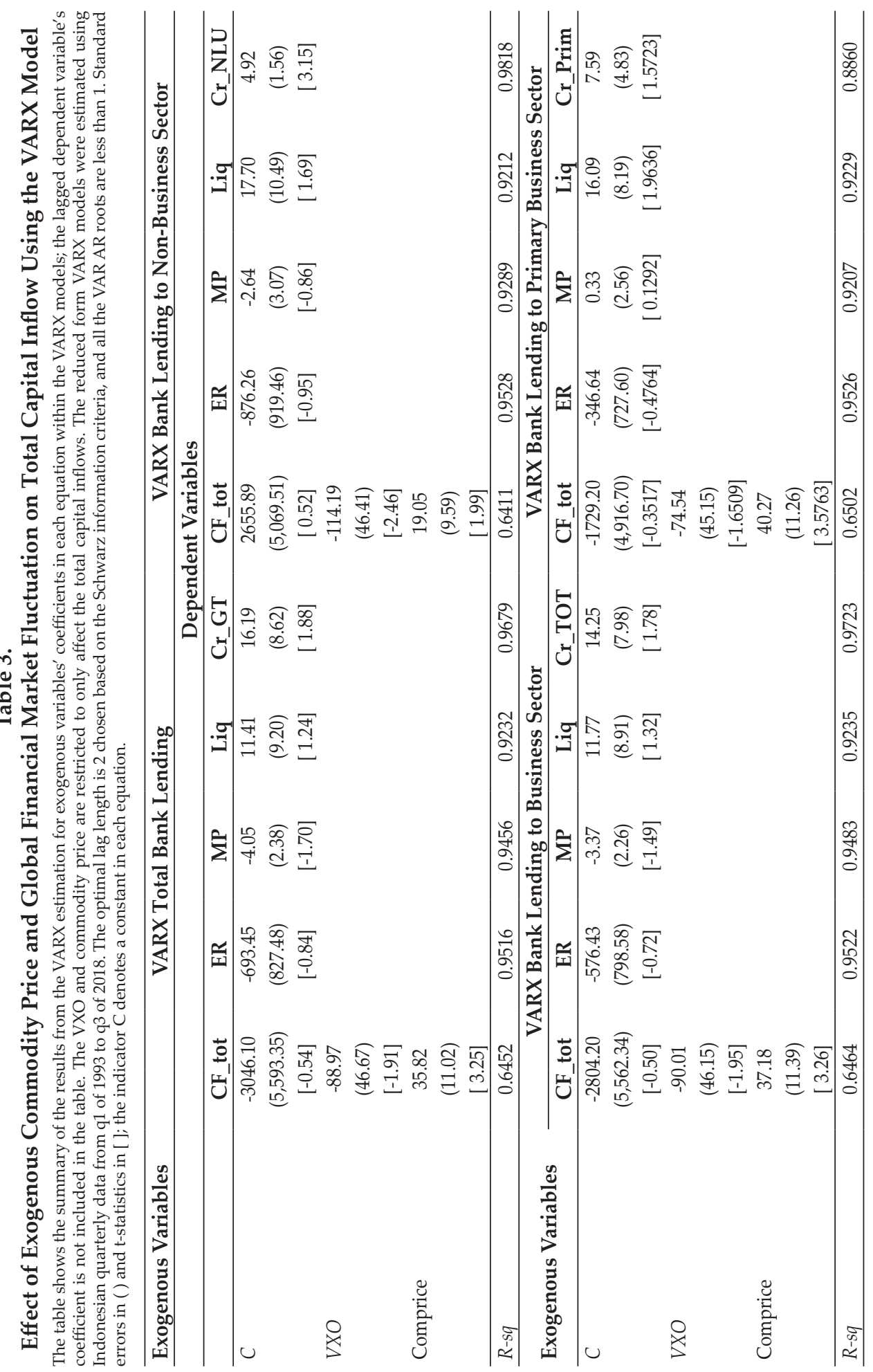




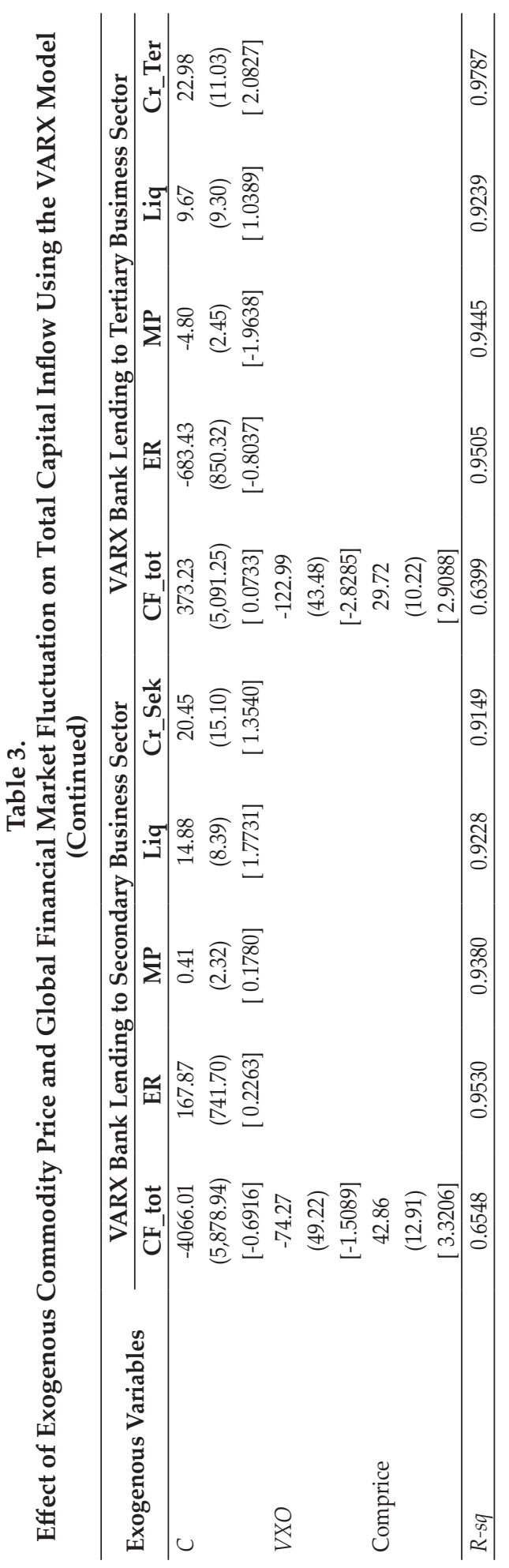




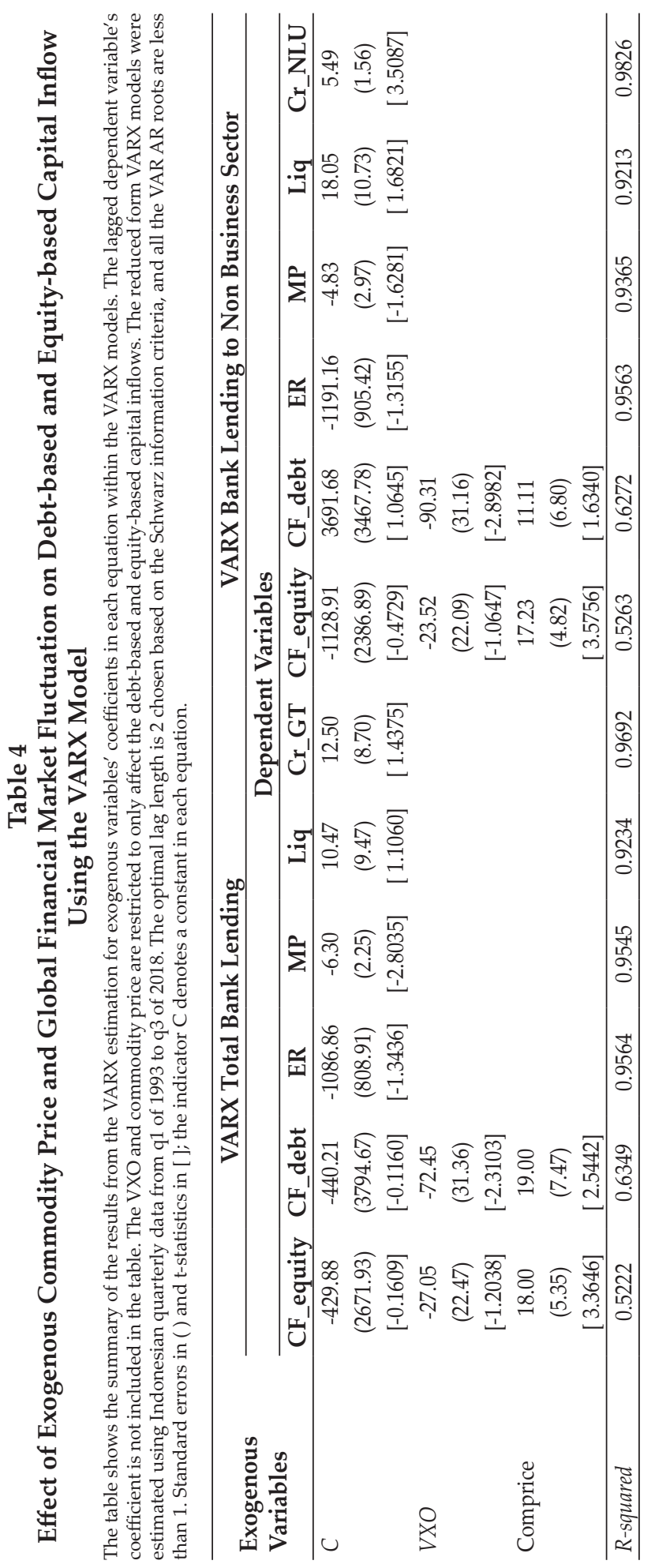




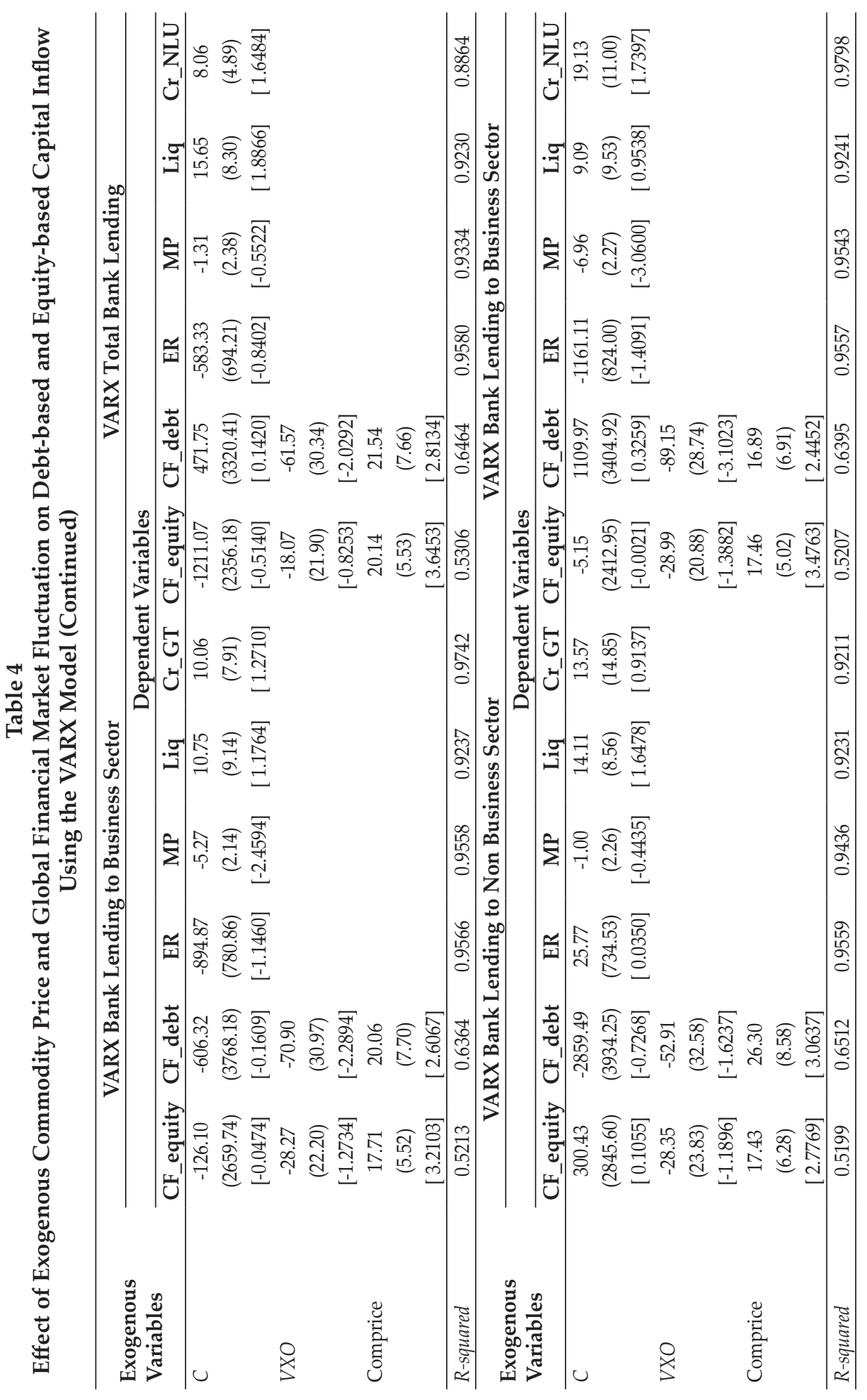


The VARX model's IRFs of bank lending to capital inflow shocks, which are shown in Appendix, Figure A.2, are very similar to those from the SVAR model. The capital inflow shock (conditional on the exogenous factors) changes the allocation of bank lending across the economic sectors in Indonesia. Specifically, the capital inflow shock expands bank lending to the non-business and the primary commodity producer sectors and contracts bank lending to the other sectors.

\section{CONCLUSION}

As the global push factors, exogenous shocks from the commodity price and the global financial market fluctuation have an important role in capital inflows to Indonesia, a commodity-dependent economy. This paper reveals that the effect of a commodity price shock is more important over a longer time horizon as compared to a global financial market shock. The robustness check shows that the commodity price effect is significant across all capital inflow measures. In contrast, the global financial market shock has a significant effect on only the debt-based capital inflows. The effect of a capital inflow shock, conditional on the exogenous the global push factors, on the bank lending allocation is not uniform across sectors of the Indonesian economy. We observe that the bank lending allocation to the primary commodity producers in the business sector and to the non-business sectors (dominated by bank lending for household consumption) is expanding, while bank lending allocation to other sectors contracts.

These findings imply that policymakers should consider the behavior of international commodity prices in their decisions. Our results emphasize the importance of assessing the vulnerability of Indonesia's sources of external finance, especially the deterioration in factors that are beyond the policymaker's control. When designing the macroprudential and/or microprudential policy response to capital inflows, the effect of capital inflows on the bank lending allocation across sectors should be considered. We found banks tend to excessively increase their supply of loans to the booming sectors. The banker's risk-taking behavior would affect the effectiveness of Indonesia's monetary policy, as explained by Satria and Juhro (2011), and would also seed a financial crisis in the future (Acharya and Naqvi, 2012). Monetary, macroprudential, and capital flow management policy-mix must consider Indonesia's commodity export price fluctuation and the sectoral bank lending re-allocation effect from capital inflow surges, particularly, debt-based capital inflow surges.

Caveats are naturally relevant. Our findings are limited to the commodity price and global financial market fluctuation as global push factors of capital inflows, and to the effect of capital inflows, conditional on the exogenous global factors, on the bank lending allocation within the Indonesian economy. Future research should analyze more rigorously within a general equilibrium framework the exogenous commodity price shock effects transmitted through capital inflows into a commodity-dependent economy's business cycle. Utilizing general equilibrium frameworks would better explain the effect of commodity price shocks on a financially constrained commodity-dependent economy's business cycle. 


\section{REFERENCES}

Acharya, V., \& Naqvi, H. (2012). The Seeds of a Crisis: A Theory of Bank Liquidity and Risk Taking Over the Business Cycle. Journal of Financial Economics, 106, 349-366. https://doi.org/10.1016/j.jfineco.2012.05.014

Agung, J., Juhro, S. M., Harmanta, \& Tarsidin. (2016). Managing Monetary and Financial Stability in a Dynamic Global Environment: Bank Indonesia's Policy Perspectives. BIS Papers, 88, 157-188.

Alfaro, L., Kalemli-Ozcan, S., \& Volosovych, V. (2007). Capital Flows in a Globalized World: The Role of Policies and Institutions. In Sebastian Edwards (Ed.), Capital Controls and Capital Flows in Emerging Economies: Policies, Practices and Consequences: Vol. ISBN 0-226 (Issue May, pp. 0-226). University of Chicago Press. http://www.nber.org/books/edwa06-1

Alfaro, L., Kalemli-Ozcan, S., \& Volosovych, V. (2008). Why Doesn't Capital Flow from Rich to Poor Countries? An Empirical Investigation. In Review of Economics and Statistics. https://doi.org/10.1162/rest.90.2.347

Antràs, P., \& Caballero, R. J. (2009). Trade and Capital Flows: A Financial Frictions Perspective. The Journal of Political Economy, 117, 701-744. https://doi.org/http://dx.doi.org/10.1086/605583

Arteta, C., Eichengreen, B., \& Wyplosz, C. (2003). When Does Capital Account Liberalization Help More Than It Hurts? In Economic Policy in the International Economy: Essays in Honor of Assaf Razin, 177-206. Cambridge University Press. https://doi.org/10.1017/CBO9780511610141.009

Azis, I. J., \& Shin, H. S. (2015). Managing Elevated Risk. In Managing Elevated Risk. https://doi.org/10.1007/978-981-287-284-5

Balakrishnan, R., Nowak, S., Panth, S., \& Wu, Y. (2013). Surging Capital Flows to Emerging Asia: Facts, Impacts and Responses. Journal of International Commerce, Economics and Policy, 04, 1350007. https://doi.org/10.1142/s1793993313500075

Basri, M. C. (2017). India and Indonesia: Lessons Learned from the 2013 Taper Tantrum. Bulletin of Indonesian Economic Studies. https://doi.org/10.1080/00074918.2017.1392922

Bastourre, D., Carrera, J., Ibarlucia, J., \& Sardi, M. (2012). Common Drivers in Emerging Market Spreads and Commodity Prices. In Working Paper 2012/57.

Benigno, G., Converse, N., \& Fornaro, L. (2015). Large Capital Inflows, Sectoral Allocation, and Economic Performance. Journal of International Money and Finance, 55, 60-87. https://doi.org/10.1016/j.jimonfin.2015.02.015

Benigno, G., \& Fornaro, L. (2014). The Financial Resource Curse. Scandinavian Journal of Economics, 116, 58-86. https://doi.org/10.1111/sjoe.12047

Bodie, Z., Kane, A., Marcus, A. J. (2014). Investment 10ed.

Botta, A. (2015). The Macroeconomics of a Financial Dutch Disease. SSRN Electronic Journal. https://doi.org/10.2139/ssrn.2682644

Bruno, V., \& Shin, H. S. (2015). Capital Flows and the Risk-taking Channel of Monetary Policy. Journal of Monetary Economics. https://doi.org/10.1016/j.jmoneco.2014.11.011

Byrne, J. P., \& Fiess, N. (2016). International Capital Flows to Emerging Markets: National and Global Determinants. Journal of International Money and Finance, 61, 82-100. https://doi.org/10.1016/j.jimonfin.2015.11.005 
Cerutti, E., Claessens, S., \& Puy, D. (2019). Push Factors and Capital Flows to Emerging Markets: Why Knowing Your Lender Matters More than Fundamentals. Journal of International Economics, 119, 133-149. https://doi.org/10.1016/j.jinteco.2019.04.006

Cerutti, E., Claessens, S., \& Rose, A. K. (2019). How Important is the Global Financial Cycle? Evidence from Capital Flows. IMF Economic Review. https://doi.org/10.1057/s41308-019-00073-5

Davis, J. S. (2014). Financial Integration and International Business Cycle Co-Movement. Journal of Monetary Economics. https://doi.org/10.1016/j.jmoneco.2014.01.007

Davis, J. S. (2015). The Macroeconomic Effects of Debt- and Equitybased Capital Inflows. Journal of Macroeconomics, 46, 81-95. https://doi.org/10.1016/j.jmacro.2015.07.006

Davis, J. S., Valente, G., \& van Wincoop, E. (2019). Global Drivers of Gross and Net Capital Flows. In Federal Reserve Bank of Dallas, Globalization Institute Working Papers, 357. https://doi.org/10.24149/gwp357

Davis, S., \& Presno, I. (2014). Capital Controls as an Instrument of Monetary Policy. In Federal Reserve Bank of Dallas, Globalization and Monetary Policy Institute Working Papers, 171. https://doi.org/10.24149/gwp171

Dreschel, T., \& Tenreyro, S. (2017). Commodity Booms and Busts in Emerging Economics. NBER Working Paper Series.

Fernández, A., González, A., \& Rodríguez, D. (2018). Sharing a Ride on the Commodities Roller Coaster: Common Factors in Business Cycles of Emerging Economies. Journal of International Economics. https://doi.org/10.1016/j.jinteco.2017.11.008

Filiz Unsal, D. (2013). Capital Flows and Financial Stability: Monetary Policy and Macroprudential Responses. International Journal of Central Banking, 9, 233-285. https://doi.org/10.5089/9781462307272.001

Forbes, K. J., \& Warnock, F. E. (2012). Capital Flow Waves: Surges, Stops, Flight, and Retrenchment. Journal of International Economics, 88, 235-251. https://doi.org/10.1016/j.jinteco.2012.03.006

Fornero, J., \& Kirchner, M. (2018). Learning about Commodity Cycles and Savinginvestment Dynamics in a Commodity-exporting Economy. International Journal of Central Banking, 14, 205-262.

Hahm, J. H., Shin, H. S., \& Shin, K. (2013). Noncore Bank Liabilities and Financial Vulnerability. Journal of Money, Credit and Banking, 45, 3-36. https://doi.org/10.1111/jmcb.12035

IMF. (2017). Indonesia, Financial System Stability Assessment.

IMF. (2018). Indonesia: 2017 Article IV ConsultationDecember 21, 2017. 18. http://www.imf.org

Jin, K. (2012). Industrial Structure and Capital Flows. American Economic Review, 102, 2111-2146. https://doi.org/10.1257/aer.102.5.2111

Koepke, R. (2019). What Drives Capital Flows to Emerging Markets? A Survey of the Empirical Literature. Journal of Economic Surveys, 33, 516-540. https://doi.org/10.1111/joes.12273

Korinek, A., \& Sandri, D. (2016). Capital Controls or Macroprudential Regulation? Journal of International Economics, 99, S27-S42. https://doi.org/10.1016/j.jinteco.2016.02.001 
Lartey, E. K. K. (2008). Capital Inflows, Dutch Disease Effects, and Monetary Policy in a Small Open Economy. Review of International Economics, 16, 971-989. https://doi.org/10.1111/j.1467-9396.2008.00762.x

Magud, N. E., Reinhart, C. M., \& Rogoff, K. S. (2011). Capital Controls: Myth and Reality, A Portfolio Balance Approach to Capital Controls. In Working Paper, 11-7; Issue February.

McKinnon, R. (2014). Hot Money Flows, Cycles in Primary Commodity Prices, and Financial Control in Developing Countries. FERDI, 109. http://journal.hep.com.cn/fec/EN/article/showOldVolumnList.do

Mehrotra, A., Miyajima, K., \& Villar, A. (2012). Developments of Domestic Government Bond Markets in EMEs and Their Implications. BIS Paper, 67, 31-50.

Nehru, V. (2013). Manufacturing in India and Indonesia: Performance and Policies. Bulletin of Indonesian Economic Studies. https://doi.org/10.1080/00074918.2013.772938

Pesaran, M. H. (2015). Time Series and Panel Data Econometrics (first edit). Oxford University Press.

Pontines, V., \& Siregar, R. (2012). Episodes of Large Exhange Rate Appreciations and Reserves Accumulations in Selected Asian Economies: Is Fear of Appreciations Justified? SSRN Electronic Journal., Article 31. https://doi.org/10.2139/ssrn.2090397

Prabheesh, K. P., Anglingkusumo, R., \& Juhro, S. M. (2020). The Dynamics of Global Financial Cycle and Domestic Economic Cycles: Evidence from India and Indonesia. Economic Modelling. https://doi.org/10.1016/j.econmod.2020.02.024

Reinhart, C. M., Reinhart, V., \& Trebesch, C. (2016). Global Cycles: Capital Flows, Commodities, and Sovereign Defaults, 1815-2015. American Economic Review, 106, 574-580. https://doi.org/10.1257/aer.p20161014

Rey, H. (2015). Dilemma not Trilemma. NBER Working Paper Series. https://doi.org/10.1017/CBO9781107415324.004

Sahay, R., Arora, V., Arvanitis, A., Faruqee, H., N’Diaye, P., \& Mancini Griffoli, T. (2014). Emerging Market Volatility: Lessons from the Taper Tantrum. Staff Discussion Notes. https://doi.org/10.5089/9781498318204.006

Samarina, A., \& Bezemer, D. (2016). Do Capital Flows Change Domestic Credit Allocation? Journal of International Money and Finance, 62, 98-121. https://doi.org/10.1016/j.jimonfin.2015.12.013

Satria, D., \& M. Juhro, S. (2011). Risk Behavior in the Transmission Mechanism of Monetary Policy in Indonesia. Buletin Ekonomi Moneter dan Perbankan, 13, 243-270. https://doi.org/10.21098/bemp.v13i3.393

Shousa, S. (2016). Macroeconomic Effects of Commodity Booms and Busts: The Role of Financial Frictions. XVIII Seminário Anual de Metas Para a Inflação Do Banco Central Do Brasil, 1-57.

Terrones, M., \& Mendoza, E. G. (2008). An Anatomy of Credit Booms: Evidence From Macro Aggregates and Micro Data. IMF Working Papers. https://doi.org/10.5089/9781451870848.001

UNCTAD. (2017). State of Commodity Dependence 2016.

Warjiyo, P. (2012). Indonesia's Monetary Policy: Coping with Volatile Commodity Prices and Capital Inflows. BIS Working Papers, 70. 
Warjiyo, P. (2013). Indonesia: Stabilizing the Exchange Rate Along Its Fundamental. BIS Paper.

Warjiyo, P. (2014). US Monetary Policy Normalization and EME Policy Mix : The Indonesian Experience. NBER 25th Annual East Asian Seminar on Economics, June, 1-10.

Warjiyo, P. (2016). Central Bank Policy Mix: Key Concepts and Indonesia's Experience. Buletin Ekonomi Moneter dan Perbankan. https://doi.org/10.21098/bemp.v18i4.573

Warjiyo, P. (2017). Indonesia: The Macroprudential Framework and the Central Bank's Policy Mix. BIS Papers, 94. 


\section{APPENDIX}

\section{Table A.1 Data Description}

The data series of this research is gathered from various sources, Indonesian Statistical Bureau (BPS), Bank Indonesia (BI), and IMF International Financial Statistics (IFS). The period of the data is from the first quarter of 1993 to the third quarter of 2018. The detailed explanation of the data is as follows:

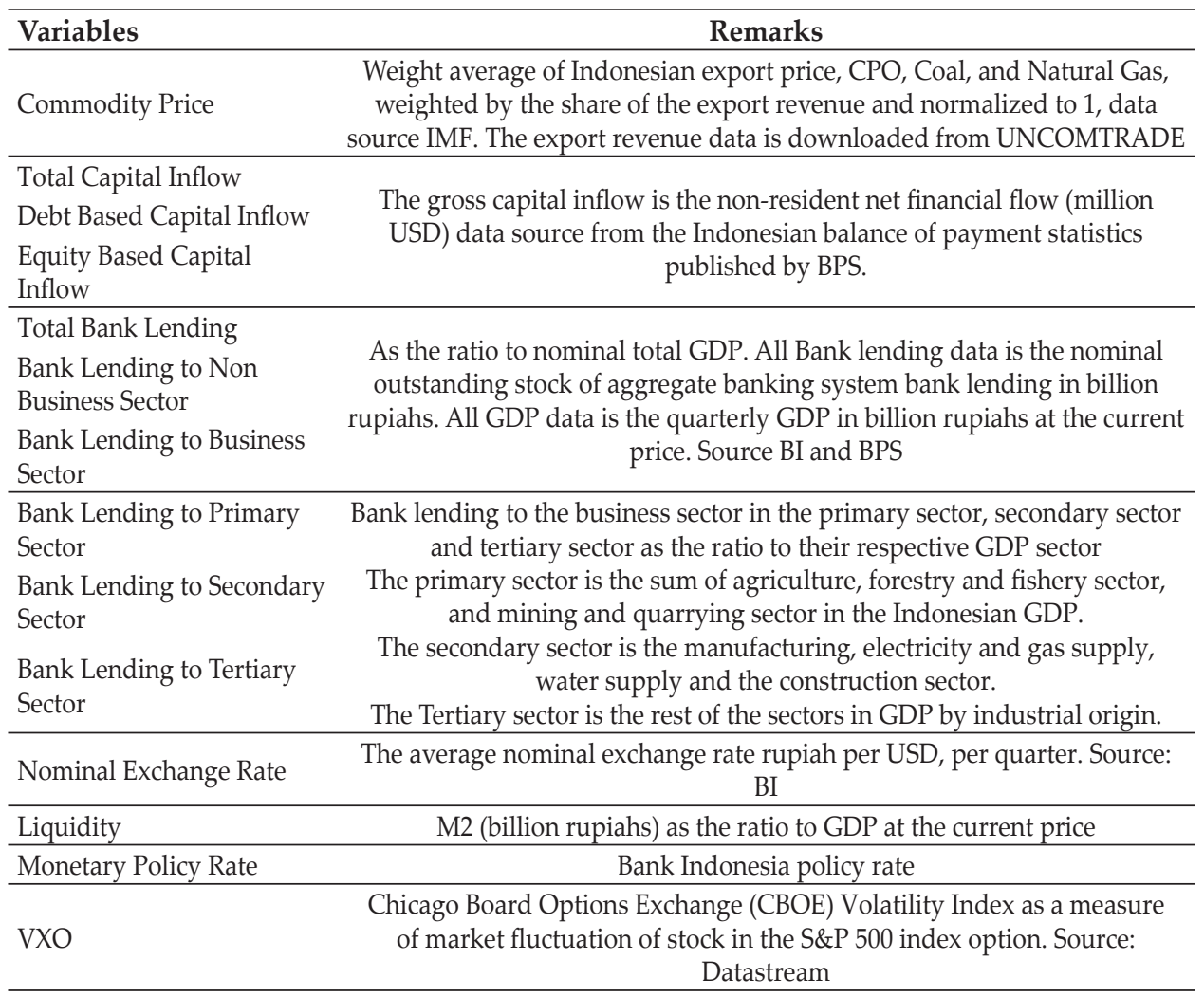


Figure A.1.

Indonesian Capital Flows, 2004-2018

This figure plots the data on capital flows in Indonesia. The first panel is the behavior of net capital flow in Indonesia decomposed into non-resident capital inflow (liabilities) and resident capital outflow (assets). The lower panel is the decomposition of capital inflow and capital outflow into debt-based and equity-based flows. All data are in thousand USD and the data are sourced from the Bank Indonesia's Indonesian Balance of Payment Statistics.

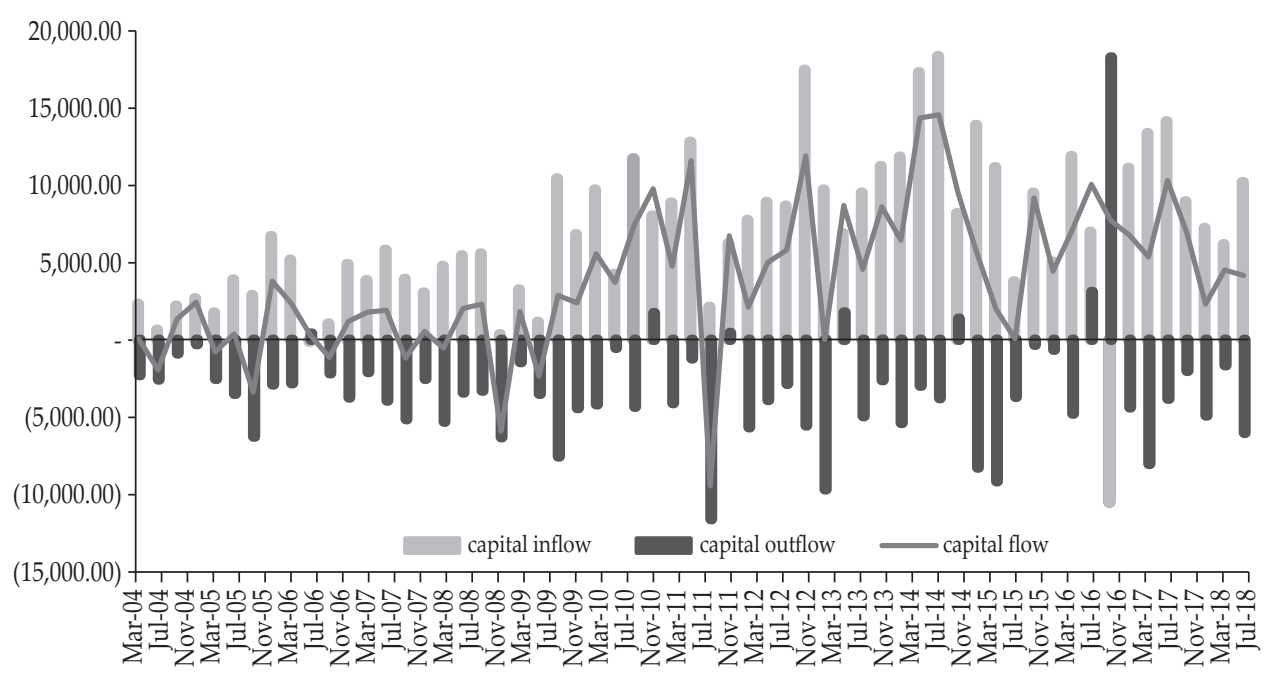

Gross Capital Inflow (liabilities) 2004-2018

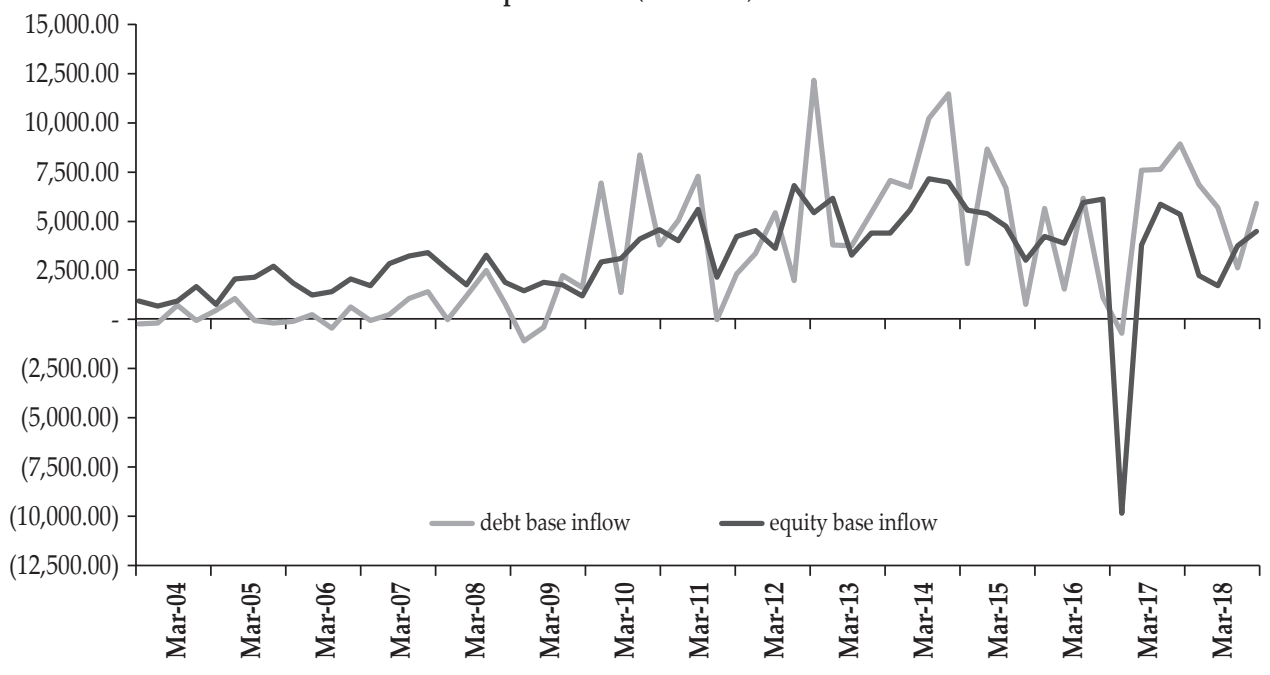


Figure A.1.

Indonesian Capital Flows, 2004-2018 (Continued)

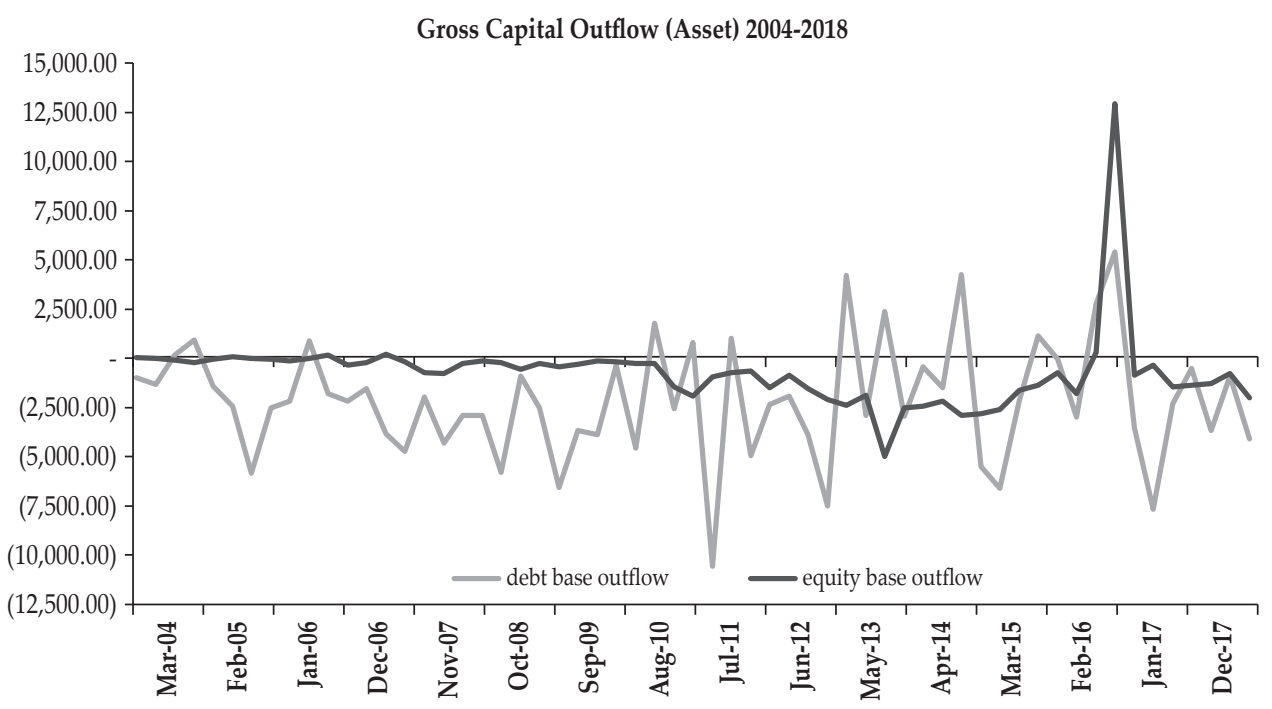

Figure A.2.

Impulse Response Functions from the VARX Model

Response of Bank Lending by Economic Sector to Total Gross Capital Inflows

The figure plots the IRFs of bank lending to VARX innovation \pm 2 standard error from the total capital inflow shock. The first row plots the IRFs of total bank lending (CR_GT), bank lending to the business sector (CR_TOT), and bank lending to the non-business sector (CR_NLU). The second row plots the IRFs of bank lending to the business sector (CR_TOT) decomposed by the economic sectors, namely, primary sector (CR_PRIM), secondary sector (CR_SEK), and tertiary sector (CR_TER). The IRFs were estimated using the VARX model employing Indonesian quarterly data from q1 1993 to q3 2018. Note that bank lending in all cases is scaled by nominal GDP.

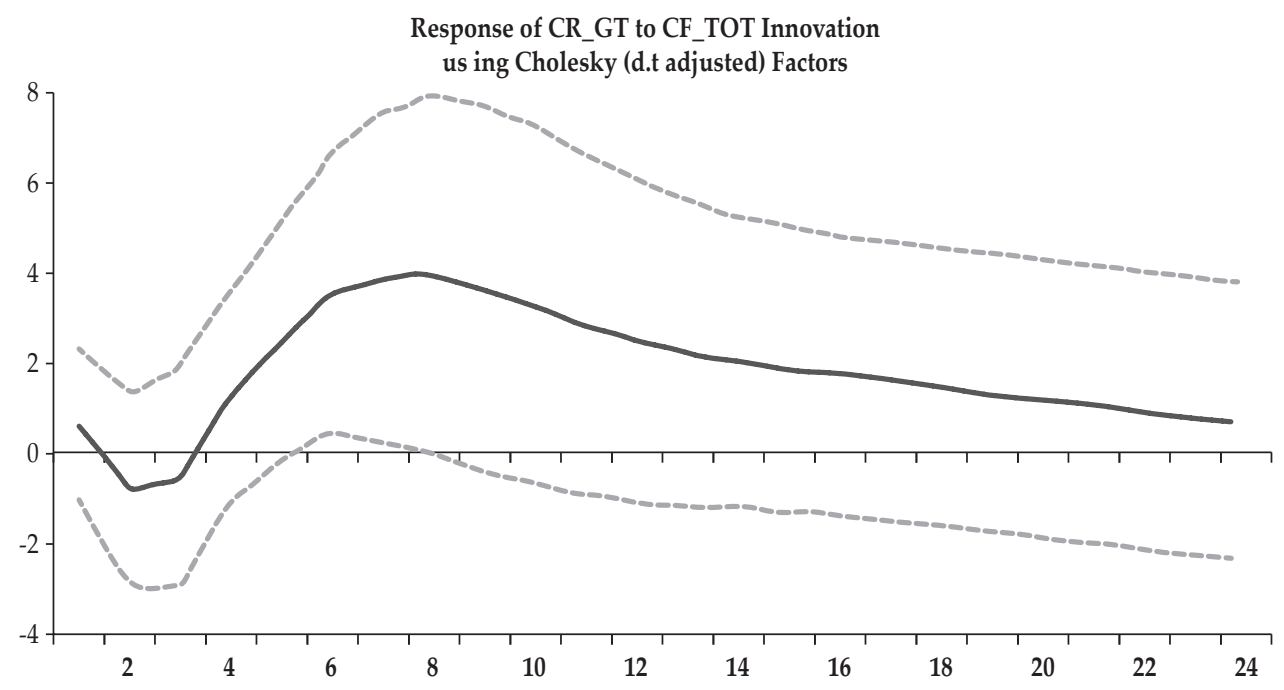


Figure A.2.

Impulse Response Functions from the VARX Model

Response of Bank Lending by Economic Sector to Total Gross Capital Inflows (Continued)

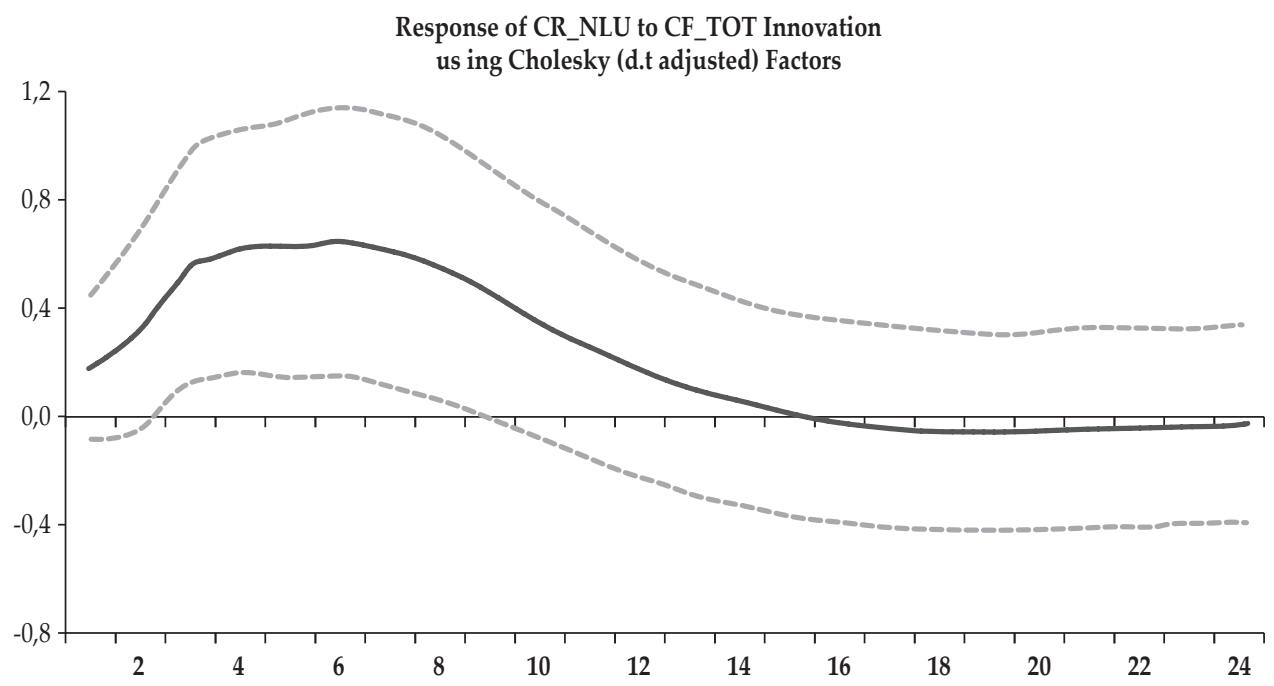

Response of CR_TOT to CF_TOT Innovation us ing Cholesky (d.t adjusted) Factors

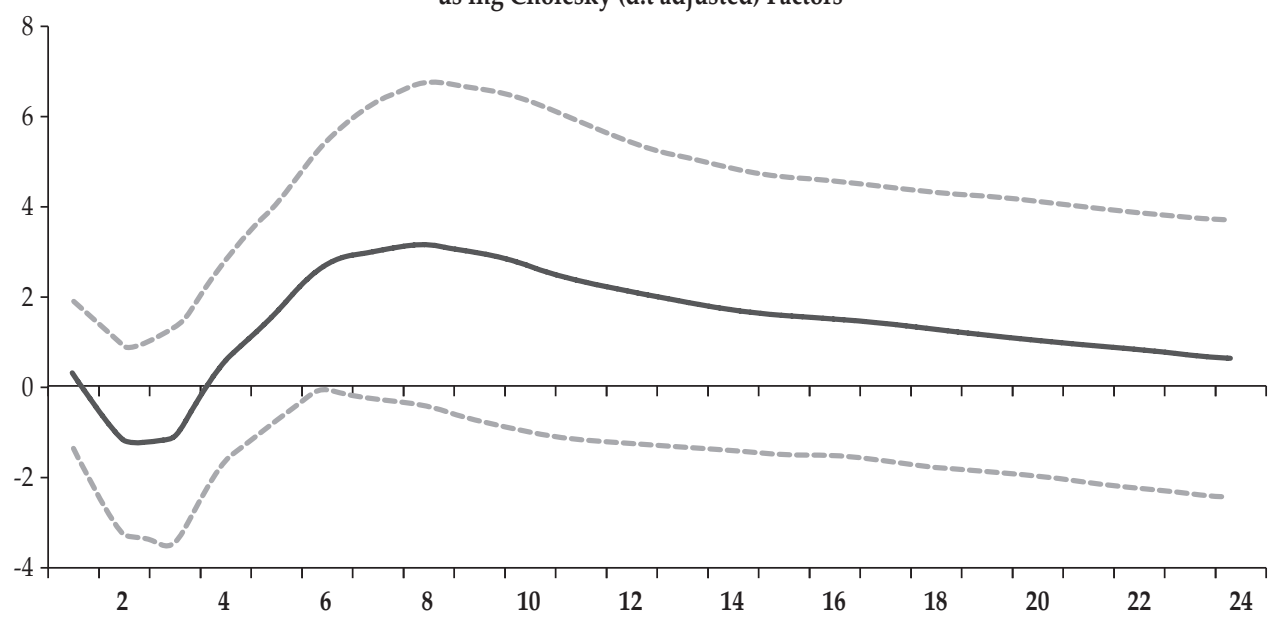


Figure A.2.

Impulse Response Functions from the VARX Model

Response of Bank Lending by Economic Sector to Total Gross Capital Inflows (Continued)

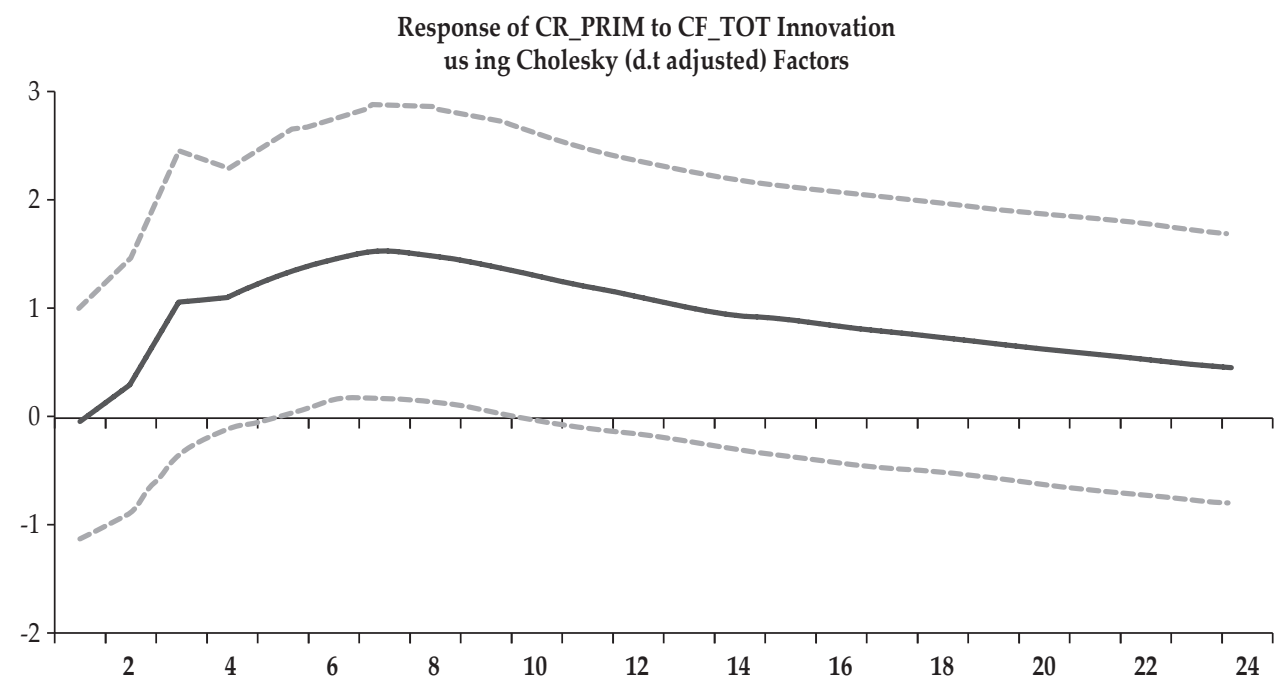

Response of CR_SEK to CF_TOT Innovation us ing Cholesky (d.t adjusted) Factors

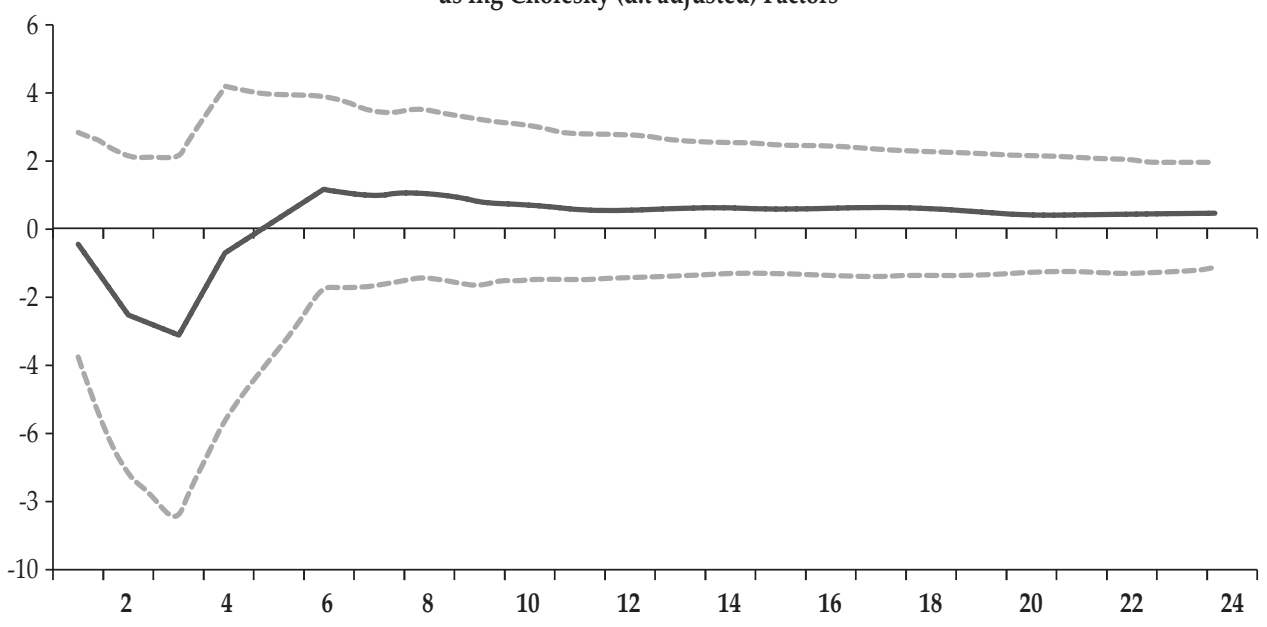


Figure A.2.

Impulse Response Functions from the VARX Model

Response of Bank Lending by Economic Sector to Total Gross Capital Inflows

(Continued)

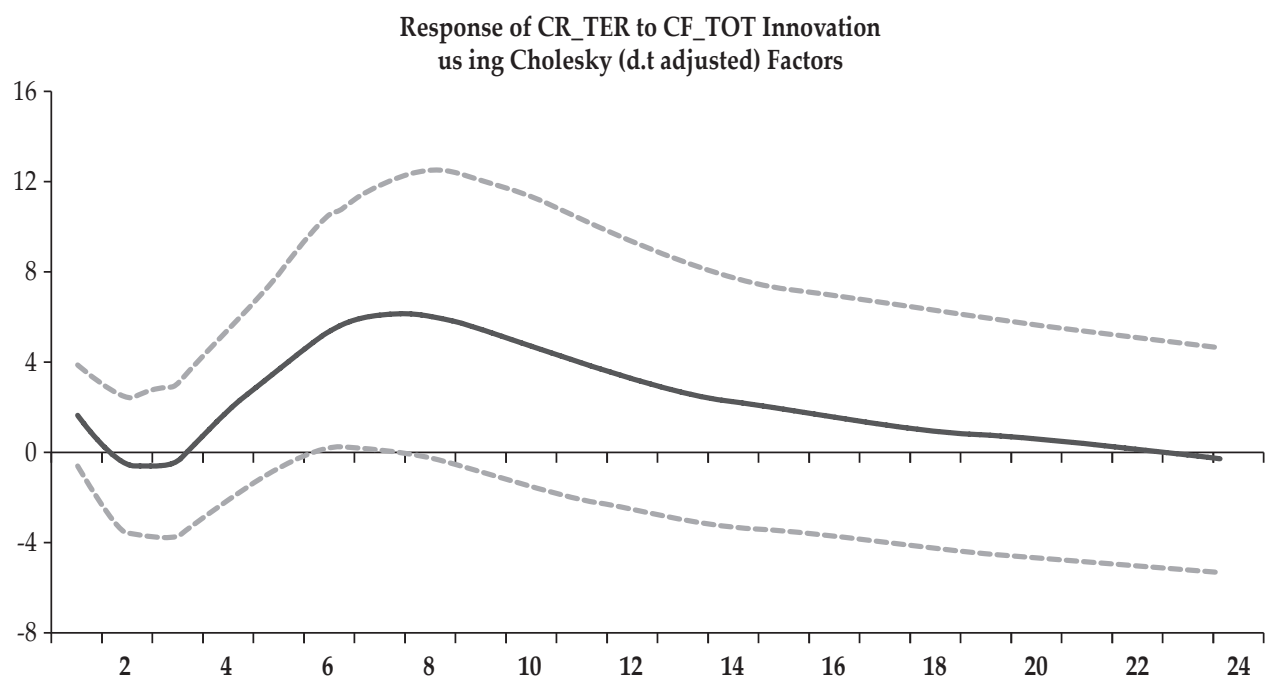

